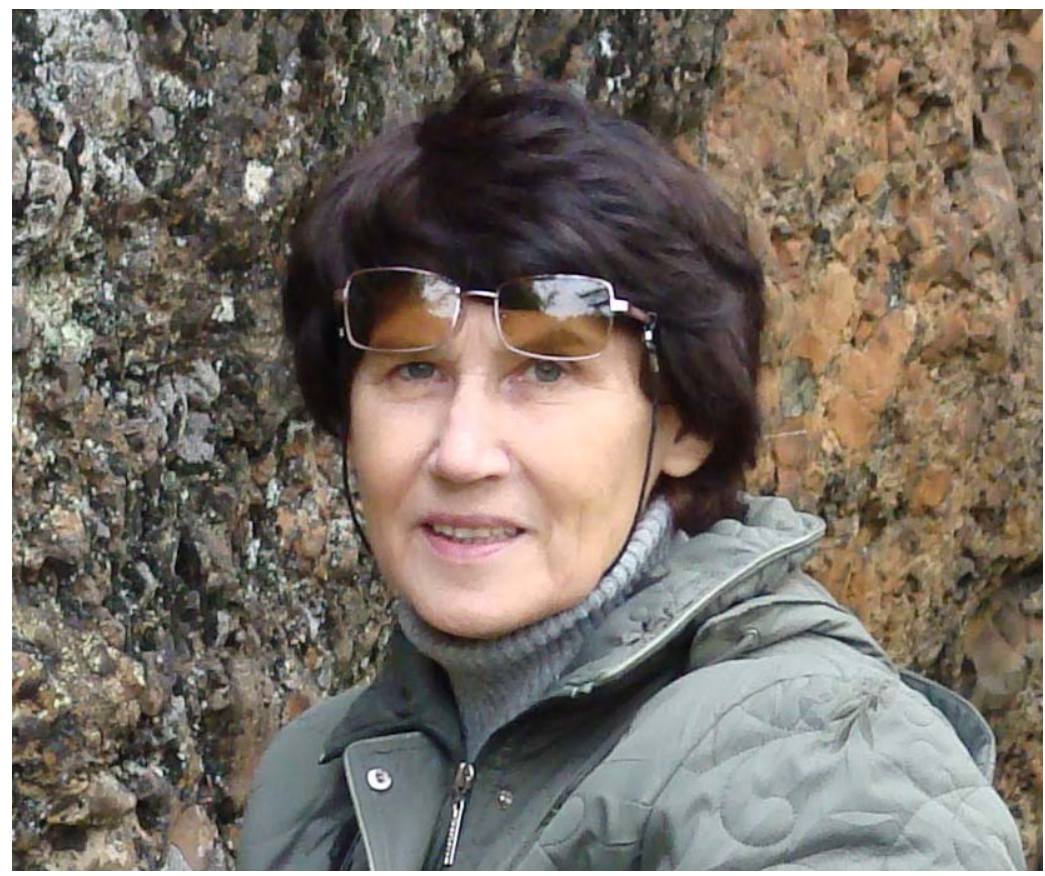

\section{TO OLGA MIKHAILOVNA AFONINA BIRTHDAY}

Olga Mikhailovna Afonina was born on January 22, 1945, in Gorushka Village, Petushki District of Vladimir Oblast (USSR). Her father, Mikhail Ivanovich, was a professional photographer in the town of Petushki while her mother, Antonina Andreevna, was a homemaker. Both Olga's brothers, the older Yury and the younger Nikolay, worked as carpenters for a living. The father had an outstanding knowledge of local wildlife and encouraged his daughter to natural studies. He was a passionate fisherman, and also had a private apiary and a large garden. He knew the forest of their neighborhood perfectly well and willingly accompanied visiting hunters - among his guests was I. D. Papanin, the famous explorer of the Russian Arctic.

In 1963, after graduating from high school in the town of Petushki, Olga entered the Biological Faculty of Moscow State University, and the Department of Geobotany was chosen by her for further specialization. Many students of the Department had been invited to various scientific expeditions to remote underexplored areas of the Soviet Union, and Olga joined one of those expeditions intending to study vegetation of the Chita Oblast in the Trans-Baikal region of South Siberia.

After graduating from the university in February 1968, Olga, together with her friend and colleague Lidiya Blagodatskikh, entered a PhD course in V. L. Komarov Botanical Institute of the USSR Academy of Sciences in Leningrad (now St. Petersburg), being directed to go there by Magadan Institute of Biological Problems of the North. Both of these young scholars started to study bryophytes. One of the supervisors of Olga's dissertation was the remarkable botanist and organizer, Prof. Boris

\section{ОЛЬГЕ МИХАЙЛОВНЕ АФОНИНОЙ КО ДНЮ РОЖДЕНИЯ}

Ольга Михайловна Афонина родилась 22 января 1945 года в деревне Горушка Петушинского района Владимирской области в семье рабочих. Отец, Михаил Иванович, работал фотографом в городе Петушки. Мать, Антонина Андреевна, была домохозяйкой. У Ольги Михайловны было два брата: старший - Юрий Михайлович, работал столяром в комбинате бытового обслуживания, младший - Николай Михайлович, был плотником на ткацкой фабрике. Любовь к ботанике О.М. привил отец, большой любитель и знаток природы. Он был страстным рыбаком, имел пасеку и большой сад. Михаил Иванович прекрасно знал окрестные леса и, в частности, сопровождал И.Д. Папанина на охоте перед его знаменитой экспедицией в Арктику.

В 1963 г. Ольга Михайловна окончила среднюю школу в городе Петушки и поступила на Биологический факультет Московского университета. В университете она познакомилась со своим сокурсником Александром Александровичем Коробковым, и их пути переплелись на всю жизнь. Александр Александрович жил в г. Лапинск, близ Петушков и они обычно ездили домой вместе. В университете Ольга Михайловна интересовалась ботаникой и специализировалась на кафедре геоботаники. В годы учебы О.М. участвовала в экспедиции в Читинскую область в качестве геоботаника. После окончания университета в феврале 1968 г. она вместе со своей подругой Лидией Савельевной Благодатских была зачислена в аспирантуру БИНа как целевая аспирантка от Магаданского института биологических проблем Севера. Большую роль в жизни 


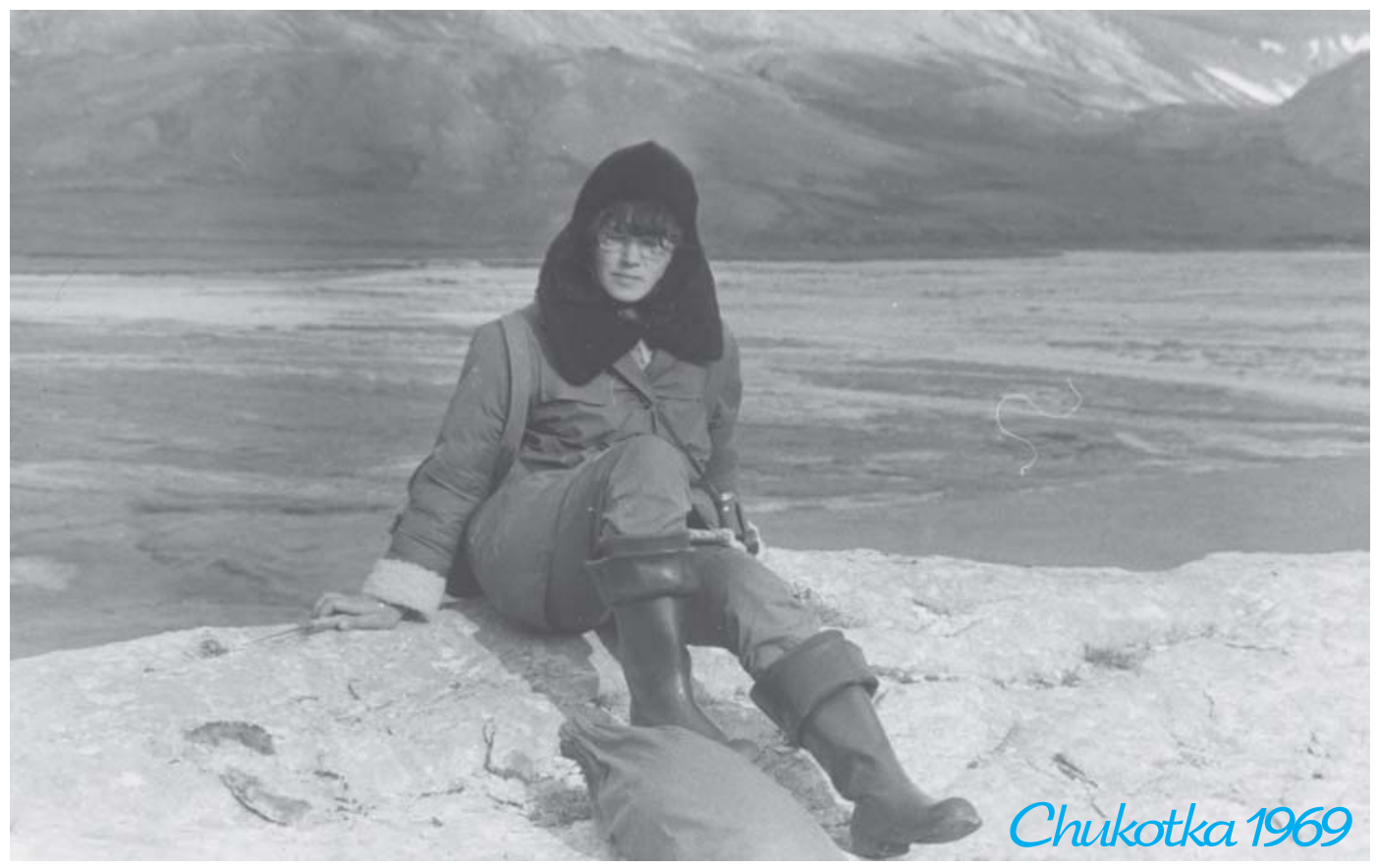

A. Tikhomirov, who headed the Laboratory of the North in the institute and who had chosen the topic of Olga's thesis and directed all subsequent paths of Olga in bryology. Moss studies were conducted immediately under the supervision of the well-known bryologist, Anastasia L. Abramova. Very soon, Olga acquired proper skills in the technique of moss identification and enthusiastically plunged into one of the most fascinating branches of cryptogamic botany - bryology. Her first bryological field season she spent as a participant of a Polar Expedition of the Botanical Institute on Taimyr Peninsula, investigating moss flora of the northernmost forest at $72^{\circ} 30^{\prime} \mathrm{N}$ latitude, the Ary-Mas vicinity. From that expedition and for a long time after her professional life would become connected with studies of mosses of the Arctic. Having fallen in love with the charming and severe nature of the Russian North, she would spend many summers in Polar expeditions.

Rich material collected by her in Chukotka in 1969 and 1970 resulted in the $\mathrm{PhD}$ candidate dissertation, "Bryoflora of Chukotka Peninsula", defended in Komarov Botanical Institute in 1974.

Within this busy period of time, happy changes in Olga's personal life occurred. In 1969, she married her former university classmate Alexander A. Korobkov. Alexander and Olga were good friends since their time as students and sharing similar interests. Having lived far from Moscow center in nearby towns, they usually travelled home together after university classes. Alexander also specialized in botany (but on vascular plants) and later advanced his education in Komarov Botanical Institute. In many years, beginning from the first Chukotka expedition and later in other regions of the country, the field research was always conducted by Olga and Alexander together. Their family has been an example of a wonderful union dedicat-
Ольги Михайловны сыграли крупнейшие отечественные ботаники, ставшие руководителями ее диссертационной работы-Борис Анатольевич Тихомиров и Анастасия Лаврентьевна Абрамова. Именно Борис Анатольевич предложил О.М. специализироваться в области бриологии. Ольга Михайловна быстро освоила подходы к определению мхов и с интересом погрузилась в это интереснейшее направление криптогамной ботаники. Летом 1968 г. она. в составе Полярной экспедиции Ботанического института поехала в экспедицию на полуостров Таймыр и с этих пор на долгие годы связала свою жизнь с изучением мхов Арктики.

В течение полевых сезонов 1969 и 1970 гг. Ольга Михайловна принимала участие в работе Чукотского отряда Полярной экспедиции БИН РАН, с которым в последующие годы была тесно связана. Обработка собранного материала проводилась под руководством А.Л. Абрамовой. В 1974 году Ольга Михайловна успешно защищает кандидатскую диссертацию «Бриофлора Чукотского полуострова», и в мае этого года ее зачисляют на должность м.н.с. отдела Низших растений БИНа. За это время в ее жизни произошли важные события. В 1969 г. она вышла замуж за Александра Александровича Коробкова, который тоже проходил учебу в аспирантуре БИНа, его специализацией были сосудистые растения. В 1971 г. у них родилась дочь Татьяна, подарившая им двоих внуков - Константина и Лизу (Elizabeth-Ann). Ольга Михайловна и Александр Александрович - пример удивительной семьи, посвятившей свою жизнь ботанике. Будучи совершенно разными по натуре, они гармонично дополняют друг друга. Во время учебы и последующей работы в БИНе они часто вместе ездили в экспедиции. 


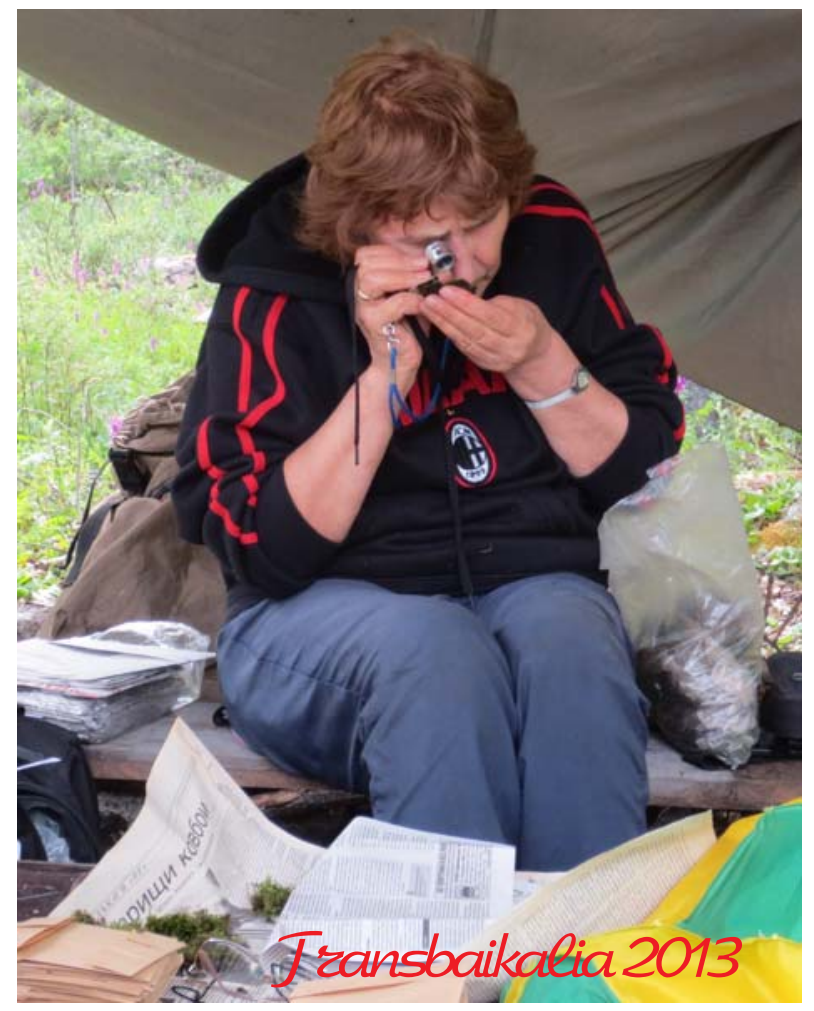

ed to the science of botany. In 1971, Olga gave birth to her daughter, Tatiana. The family has grown further by grandchildren, Konstantin and Elizabeth-Ann.

After defending her dissertation, Olga assumed the position of a researcher in the Botanical Institute, and during the period from 1974 through 1991, continued floristic exploration of the north-eastern Asia, in particular, the north of Russian Far East, islands of Arctic Ocean and northeastern Yakutia. Her materials from different parts of Chukotka Peninsula (she visited as many as 61 localities of this remote corner of Russia!) amounted to 20000 bryophyte specimens. The mosses were treated by Olga herself, while hepatics were identified by her Czech collaborator, Josef Duda. Thus, in 1988 a preprint edition of "Mosses of the Chukotka Peninsula" and, a little later, an account of hepatics appeared (Afonina 1988a, b; Afonina \& Duda, 1993). In 2000 Olga defended her Doctor of Science Thesis. Subsequent meticulous revision of certain genera yielded in publication in 2004 of a revised moss flora of Chukotka, 467 species.

All during her professional career, Olga travelled a lot. In whatever region she visited she explored with a keen eye and managed to find something new spotting rare and unusual taxa in the field. When working on her dissertation on Chukotka, Olga visited neighboring regions, including Alaska in 1992-1993, where she found a number of species common with Chukotka, which were not known in North America before. In 2005, Olga returned to the study area of her first expedition, the TransBaikal region, starting the series of projects on bryophyte exploration of the territory previously neglected by bryologists, as rather xeric conditions caused a misleading
После защиты диссертации Ольга Михайловна в течение многих лет с 1974 по 1991 гг. продолжала изучать бриофлору севера Дальнего Востока в составе Полярных экспедиций БИНа в самых труднодоступных районах Чукотского п-ова, бассейна р. Анадырь, о-ва Врангель. Результаты исследований опубликованы в серии статей. В 1979-1980 и 1982-1983 гг. она - начальник Анадырского отряда II-ой Полярной экспедиции БИН. Ею был обследован 61 географический пункт на Чукотке и собрано свыше 20000 образцов мохообразных. Помимо мхов, Ольга Михайловна собирала также печеночники. Определение коллекций печеночников производилось чешским гепатикологом Й. Дуда. В ходе изучения бриофлоры Чукотки Ольга Михайловна обработала обширные коллекции с этих территорий других участников экспедиции и гербарные материалы БИНа. В результате проделанной работы в 1988 г. О.М. издает препринт монографии «Листостебельные мхи Чукотского полуострова» в 2-х частях (Афонина, 1988а, б), а в 1993 г. совместно с Й. Дуда публикует обобщающую сводку по печеночникам Чукотки (Афонина, Дуда, 1993).

Обширный опыт полевых и лабораторных/камеральных работ, наблюдательность и любовь к своему делу позволяют Ольге Михайловне собирать богатейшие коллекции мохообразных, содержащие много редких видов, в том числе с обычно пропускаемыми при сборах гаметофорами очень мелких размеров. По ее сборам описаны новые для науки таксоны, в том числе Bucklandiella afoninae, редкий вид, произрастающий на севере дальнего Востока, Bucklandiella microcarpa fo. afoninae, а также выявлены многочисленные новые для флоры России виды мхов.

Наряду с активными полевыми и камеральными исследованиями Ольга Михайловна посвящает значительную часть своего времени научно-организационной деятельности и работе по охране природы. Она принципиальна в выборе направлений исследований. Из серьезных научных зарубежных поездок Ольги Михайловны следует упомянуть экспедиции 1992-1993 гг. на п-в Сьюард, Аляска, для изучения бриофлоры Bering Land Bridge National Preserve, a также полевые работы в Арктической и Южной Аляске, выполнявшиеся в середине 90-х годов. Особым опытом была поездка 1991 года в бриологический гербарий Пекинского института ботаники для проведения совместных бриологических исследований.

Важным, хотя порой и незаметным аспектом работы Ольги Михайловны является объединение бриологов бывшего СССР. В начале 90-х годов она. выполняла обязанности председателя секции бриологии при Научном Совете, по координации бриологических исследований в России.

Ольгу Михайловну хорошо знают и в России и за рубежом. Она участвовала в международной програм- 


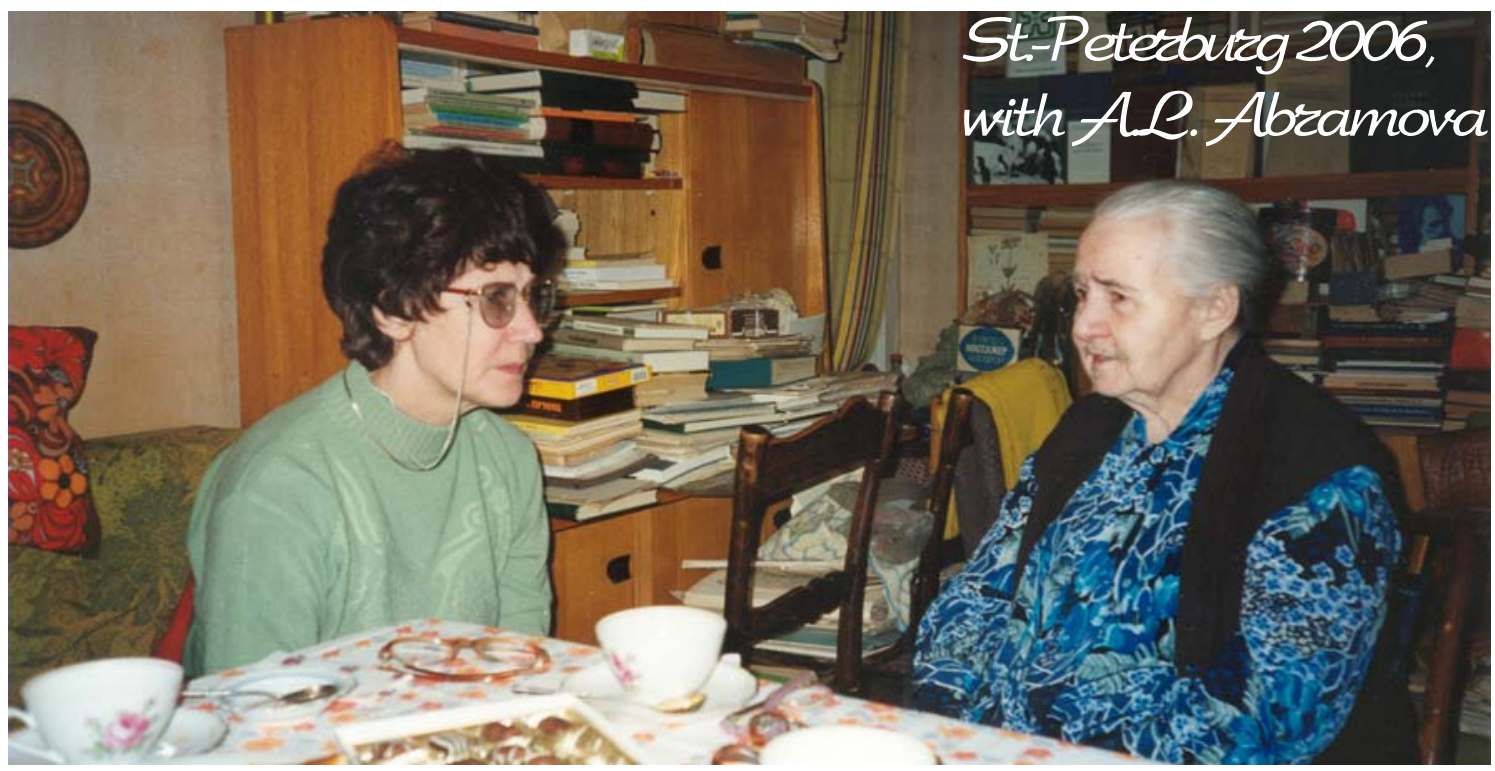

impression of the moss flora to be poor and boring to study. Olga's collections from several expeditions (including those continued in 2014) refuted this idea, as many highly disjunctive and new for the science species were discovered. The bryophyte flora of a large area of the Sokhondo Nature Reserve was published in 2012.

After passing away of Dr. Ivan I. Abramov in 1990, O. M. Afonina became the curator of the Bryophyte Herbarium in the V. L. Komarov Botanical Institute, the largest bryophyte collection in Russia. Her efforts helped maintain and enrich the collection during rather difficult times of insufficient funding, as well as keep the specimen loan process. She organized the edition of "Bryotheca Rossica" exciccates, which were issued in 1995 (\#\# 1-400), and later, in 2004-2014, regularly publishing and distributing them on an exchange basis with many world bryological herbaria. O.M. Afonina successfully collaborates with foreign colleagues participating in international bryophyte mapping projects and other cooperative research programs.

The most important activity of Olga was concentrated on the integration of bryophyte studies in the Soviet Union and then in Russia. In the beginning of 1990s, she headed the bryology section in Russian Academy of Sciences's Coordination Committee. For many years, she had served on editorial boards of national botanical journals, such as "Botanichesky Zhurnal", "Novosti Systematiki Nizshikh Rasteny" (the periodical of the Botanical Institute) and the first Russian bryological journal "Arctoa". O.M. Afonina is one of the editors of the checklists of mosses of the territory of the former Soviet Union (Ignatov \& Afonina, 1992) and East Europe and North Asia (Ignatov, Afonina, Ignatova et al., 2006). Her contributions to the moss flora of Russia included a number of difficult genera, i.e., Stereodon, Hypnum, Didymodon, Drummondia, Syntrichia, Pylaisiadelpha, Leptopterigynandrum, Ditrichiopsis, etc. She is a coauthor of three ме по картированию бриофитов Европы.

Опыт и широкий бриологический кругозор Ольги Михайловны явились важной составляющей при подготовке первого списка мхов СССР (Ignatov \& Afonina, 1992).

В конце 90-х начале 2000-х годов Ольга Михайловна работала над изучением флоры, систематики и географии мхов арктических и субарктических регионов. По материалам многолетних исследований флоры мхов Чукотки О.М. в 2000 г. успешно защищает докторскую диссертацию, а в 2004 г. издает монографию «Конспект флоры мхов Чукотки», в которой подробно охарактеризованы экология, распространение и встречаемость в Чукотском автономном округе для 467 видов мхов, для ряда редких видов приведены оригинальные рисунки и карты распространения в мире. Также в это время в рамках темы «Флора мхов и лишайников Арктики» Ольга Михайловна определяет обширные коллекции с Аляски, Канадского Арктического архипелага, архипелага Северная Земля и по результатам исследований публикует ряд статей. Начиная с 2005 г. О.М. активно изучает флору мхов Байкальской Сибири. В 2005-2014 гг. она участвовала в экспедициях и собирала материал в слабо изученных и труднодоступных районах Забайкальского края и Бурятии. По результатам исследований флоры Сохондинского заповедника в 2012 г. ею с соавторами была опубликована монография «Мхи и печеночники Сохондинского государственного заповедника».

Ольга Михайловна, будучи опытнейшим бриологом, в ходе определения коллекций часто сталкивается с необходимостью таксономических исследований, которые ее увлекают. Так, в рамках проекта «Флора мхов России» она выполнила обработки родов Stereodon, Hypnum, Didymodon, Drummondia, Syntrichia, Pylaisiadelpha, Leptopterigynandrum, Ditrichopsis и др., выявила много новых для территории России 


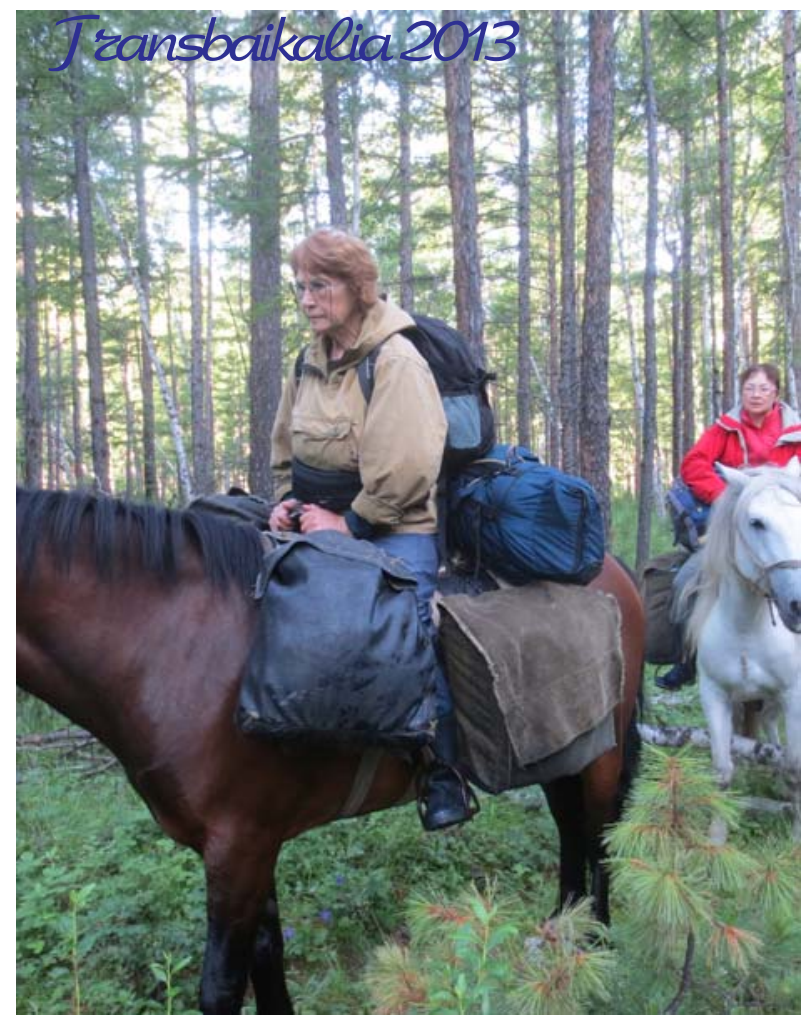

new species, Didymodon zanderi Afonina \& Ignatova, Ditrichiopsis baikalensis Ignatova \& Afonina, Grimmia jacutica Ignatova, Bednarek-Ochyra, Afonina \& J. Muñoz, and Schistidium frahmianum Ochyra \& Afonina.

The theses on the bryophyte flora of southeastern Yakutia (Krivoshapkin, 1998) and the systematic studies of the genus Plagiothecium (Doroshina, 2002) were successfully defended by students supervised by O.M. Afonina. She also consulted colleagues on their bryological projects in different regions of Russia, i.e., Irina Czernyadjeva (Putorana Plateau), Ekaterina Kuzmina (Koryakskoe Upland), Lyubov Kurbatova (Leningrad Province) and others.

Being open and modest, hospitable and very kind, Olga is always ready to help her colleagues in various difficult situations, both professional and personal. The working atmosphere created by her in the Bryophyte Research Group of the Botanical Institute promotes successful floristic and taxonomic studies by the institute staff and numerous visiting scholars.

O.M. Afonina gives greatly of herself in professional service. In honor of her, the newly described species found on the north of Russian Far East, Bucklandiella afoninae, was named.

We all greatly appreciate Olga's work for bryology by presenting this volume to her anniversary, hoping she will continue to conduct her research sharing the knowledge and experience with her colleagues, providing an example to follow with her life-time service to science and nature conservation. видов. Ольга Михайловна описала ряд новых для науки видов, таких как Didymodon zanderi Afonina \& Ignatova, Ditrichopsis baicalensis Ignatova \& Afonina, Grimmia jacutica Ignatova, Bednarek-Ochyra, Afonina \& J.Muñoz, Schistidium frahmianum Ochyra \& Afonina.

Под руководством Ольги Михайловны были успешно подготовлены и защищены 2 кандидатские диссертации: по бриофлоре юго-восточной Якутии К.К. Кривошапкиным в 1998 г. и по систематике рода Plagiothecium Г.Я. Дорошиной в 2002 году. Кроме того, Ольга Михайловна оказала большую помощь на первых этапах изучения мхов И.В. Чернядьевой, Е.Ю. Кузьминой и Л.Е. Курбатовой и была консультантом при подготовке кандидатских диссертаций И.В. Чернядьевой по флоре мхов плато Путорана, Е.Ю. Кузьминой по флоре мхов Корякского нагорья и Л.Е. Курбатовой по флоре мхов Ленинградской области.

Продолжая традицию крупнейших бриологов БИНа, О.М. организовала издание эксикат мхов “Bryotheca Rossica”. Первые 4 выпуска вышли в 1995 г. и включали 100 образцов. В дальнейшем эксикаты выпускались регулярно с 2004 по 2014 гг.

Ольга Михайловна является куратором бриологического гербария и проводит большую работу по сохранению и пополнению коллекционного фонда БИНа. Благодаря ее усилиям за последние годы значительно улучшилось состояние хранения гербарных коллекций, постоянно приводятся в порядок гербарий отдельных групп мхов, активно пополняется гербарный фонд. Ведется большой обмен дублетными материалами с ведущими гербариями мира.

Ольга Михайловна выполняет большую редакционную работу, в течении многих лет она принимает активное участие в составе редколлегий ведущих ботанических изданий страны - “Ботанический журнал”, “Аrctoa”. С 1992 по 2005 года она была членом редколлегии журнала "Новости систематики низших растений”.

Ольга Михайловна всегда скромна и доброжелательна. Она открыта для близких и всегда готова помочь в сложных жизненных ситуациях. Следует особо подчеркнуть скромное отношение Ольги Михайловны к результатам собственных исследований, сочетающееся с активным поиском путей решения сложных и спорных научных проблем.

Ольга Михайловна Афонина - удивительный человек, смелый и принципиальный исследователь, одна из крупнейших знатоков мхов России, скромная и обаятельная, радушная и гостеприимная женщина, объединившая вокруг себя бриологов БИНа.

Поздравляя Ольгу Михайловну, мы посвящаем ей этот том и желаем дальнейших творческих успехов и захватывающих открытий! 


\section{ПУБЛИКАЦИИ \\ ОЛЬГИ МИХАЙЛОВНЫ АФОНИНОЙ}

[AFONINA, O.M.] АФОНИНА О.М. 1972. Новые и редкие виды мхов для Чукотского полуострова. - [The new and rare moss species for the Chukotka Peninsula] Новости сист. низи. раст. [Novosti Sist. Nizsh. Rast.] 9: 364-371.

[ABRAMOV, I.I., A.L. ABRAMOVA, O.M. AFONINA \& L.S. BLAGODATSKICН] АБРАМОВ И.И., А.Л. АБРАМОВА, О.М. АФОНИНА, Л.С. БЛАГОДАТСКИХ. 1972. Арктическая бриофлора CCСР и некоторые ее особенности. - [The arctic bryoflora of the USSR and some its peculiarities] Тезисы докл.: IV Закавказское совещание по спор. раст. Ереван, 1972 (ред. Д.Н. Tетеревникова-Бабаян) [Abstracts: Teterevnikov-Babayan D.N. (ed.) IV Zakavkazskoe soveshchanie po sporovym rasteniyam] Ереван [Erevan]: 63-64.

[AFONINA, O.M.] АФОНИНА О.М. 1973. Новые виды мхов для Чукотского полуострова. - [The new moss species for the Chukotka Peninsula] Новости сист. низи. pacm. [Novosti Sist. Nizsh. Rast.] 10: 317-324.

[ABRAMOV, I.I., A.L. ABRAMOVA, O.M. AFONINA \& L.S. BLAGODATSKICH] АБРАМОВ И.И., А.Л. АБРАМОВА, О.М. АФОНИНА, Л.С. БЛАГОДАТСКИХ. 1973. Арктическая флора мхов СССР и ее особенности. - [The arctic bryoflora of the USSR and its peculiarities] Тезисы докл.: V Делегатский съезд бот. об-ва. Киев, АН СССР ВБО и АН УССР УБО. [Abstracts: V Delegatskii s'ezd botanicheskogo abshchestva. Kiev, AN SSSR VBO $i$ AN USSR UBO]: 174-176.

[AFONINA, O.M.] АФОНИНА О.М. 1974. Характеристика некоторых конкретных бриофлор Чукотского полуострова. - [Description of the some local bryofloras of the Chukotka Peninsula] Бот. Журн. [Bot. Zhurn.] 59(2): 192-205.

[AFONINA, O.M.] АФОНИНА О.М. 1974. Бриофлора Чукотского полуострова. - [The moss flora of the Chukotka Peninsula] Автореф. дисс. на соиск. ... к.б.н. [Ph. D. Thesis] Л. [Leningrad]: $1-21$.

[AFONINA, O.M.] АФОНИНА О.М. 1974. Бриофлора Чукотского полуострова. - [The moss flora of the Chukotka Peninsula] Дисс. на соиск. ... к.б.н. [Ph. Diss.] Л. [Leningrad]: 1-135.

[ABRAMOVA, A.L., O.M. AFONINA \& J. DUDA] АБРАМОВА А.Л., О.М. АФОНИНА, Й. ДУДА. 1974. К флоре печеночных мхов Чукотского полуострова. - [То the liverwort flora of the Chukotka Peninsula] Новости сист. низи. pacm. [Novosti Sist. Nizsh. Rast.] 11: 311-317.

[ABRAMOV, I.I., A.L. ABRAMOVA, O.M. AFONINA \& L.S. BLAGODATSKICH] АБРАМОВ И.И., А.Л. АБРАМОВА, О.М. АФОНИНА, Л.С. БЛАГОДАТСКИХ. 1975. Арктическая флора мхов СССР и ее особенности. - [The arctic moss flora of the USSR and its peculiarities] Новости сист. низи. pacm. [Novosti Sist. Nizsh. Rast.] 12: 273-283.

[AFONINA, O.M.] АФОНИНА О.М. 1976. Материалы к бриофлоре Чукотского полуострова. - [Contribution to the bryoflora of the Chukotka Peninsula] В кн.: Флора и растительность Магаданской области (ред. Хохряков, А. П.) [In: Hohryakov, A.P. (ed.) Flora i rastitelnost Magadan oblast] Владивосток, АН СССР, ИПБС [Vladivostok, AN USSR]: 64-108.

[ABRAMOVA, A.L., O.M. AFONINA \& J. DUDA] АБРАМОВА А.Л., О.М. АФОНИНА, Й. ДУДА. 1976. К флоре печеночных мхов Чукотского полуострова. II. - [To the liverwort flora of the Chukotka Peninsula. II] Hовости сист. низи. pacm. [Novosti Sist. Nizsh. Rast.] 13: 208-219.

[AFONINA, O.M.] АФОНИНА О.М. 1978. Флора листостебельных мхов. - [The moss flora] B кн.: Apы-Maс. Природные

\section{PUBLICATIONS OF \\ OLGA M. AFONINA}

условия, флора и растительность (ред. Норин, Б. Н.) [In: Norin, B.N. (ed.) Ary-Mas. Prirodniya usloviya, flora i rastitelnost]. Ленинград, Наука [Leningrad, Nauka]: 87-97.

[AFONINA, O.M. \& J. DUDA] АФОНИНА О.М., Й. ДУДА. 1978 К флоре печеночных мхов низовьев реки Индигирки. - [То the liverwort flora from the Lower Indigirka River] Новости сист. низи. pacm. [Novosti Sist. Nizsh. Rast.] 15: 212-218.

[AFONINA, O.M., L.I. BREDKINA \& I.I. MAKAROVA] АФОНИНА О.М., Л.И. БРЕДКИНА, И.И. МАКАРОВА. 1979. Мхи и лишайники лесостепного ландшафта в среднем течении p. Индигирки. - [Mosses and lichens of the forest-steppe landscape in the Middle Indigirka River] Новости сист. низи. раст. [Novosti Sist. Nizsh. Rast.] 16: 175-186.

[AFONINA, O.M., A.L. ABRAMOVA, \& J. DUDA] АФОНИНА О.М., А.Л. АБРАМОВА, Й. ДУДА. 1980. К флоре печеночных мхов Чукотского полуострова. III. - [То the liverwort flora of the Chukotka Peninsula. III] Новости сист. низи. раст. [Novosti Sist. Nizsh. Rast.] 17: 204-211.

[AFONINA, O.M. \& J. DUDA] АФОНИНА О.М., Й. ДУДА. 1980. К флоре печеночных мхов среднего течения р. Индигирки. [To the liverwort flora of the Middle Indigirka River] Новости cuст. низи. pacm. [Novosti Sist. Nizsh. Rast.] 17: 211-216.

[AFONINA, O.M.] АФОНИНА О.М. 1980. Дополнения к флоре листостебельных мхов Чукотского полуострова. I. - [Additions to the moss flora of the Chukotka Peninsula. I.] Новости сист. низи. pacm. [Novosti Sist. Nizsh. Rast.] 17: 241-244.

[AFONINA, O.M., L.I. BREDKINA \& I.I. MAKAROVA] АФОНИНА О.М., Л.И. БРЕДКИНА, И.И. МАКАРОВА. 1980. Распределение лишайников и мхов в лесостепных ландшафтах в среднем течении р. Индигирки. - [Distribution of mosses and lichens of the forest-steppe landscape in the Middle Indigirka River] Бот. Журн. [Bot. Zhurn.] 65(1): 66-83.

[AFONINA, O.M.] АФОНИНА О.М. 1981. О видах рода Drepanocladus на Чукотском полуострове. - [On Drepanocladus species from the Chukotka Peninsula] Тезисы докл.: Бриолихенологические исследования высокогорных районов и севера CCCP. [Abstracts: Brio-lihenologicheskie issledovaniya vysokogornyh rajonov i severa SSSR] Anamumb [Apatity]: 20-21.

[AFONINA, O.M. \& I.I. MAKAROVA] АФОНИНА O.М., И.И. МАКАРОВА. 1981. Парциальная флора окружения горячих ключей: мхи и лишайники. - [The partial flora of surroundings of hot springs: mosses and lichens] Экосистемь термальных источников Чукотского полуострова. [Ekosistemy termalnyh istochnikov Chukotskogo poluostrova] Л., Наука [Leningrad, Nauka]: 78-94.

[AFONINA, O.M \& V.I. PERFIL'EVA] АФОНИНА O.M., В.Н ПЕРФИЛЬЕВА. 1981. Листостебельные мхи северо-востока Якутии (Верхоянский район). - [Mosses of the north-east Yakutiya (Verkhoyansk Region)] Новости сист. низи. раст. [Novosti Sist. Nizsh. Rast.] 18: 188-199.

[AFONINA, O.M., A.L. ABRAMOVA, \& J. DUDA] АФОНИНА О.М., А.Л. АБРАМОВА, Й. ДУДА. 1982. К флоре печеночных мхов Чукотского полуострова. IV. - [Tо the liverwort flora of the Chukotka Peninsula. IV] Hовости сист. низи. раст. [Novosti Sist. Nizsh. Rast.] 19: 184-187.

[AFONINA, O.M.] АФОНИНА O.M. 1982. Дополнения к флоре мхов Чукотского полуострова. 2. - [Additions to the moss flora of the Chukotka Peninsula. 2.] Новости сист. низи. pacm. [Novosti Sist. Nizsh. Rast.] 19: 187-190.

[ABRAMOVA, A.L. \& O.M. AFONINA] АБРАМОВА А.Л., О.М 
АФОНИНА. 1983. О связи флор печеночных мхов Чукотского полуострова и Арктической Аляски. - [On relationships of liverwort floras of the Chukotka Peninsula and the Arctic Alaska] Тезисы докл.: Х Всесоюзный симпозиум "Биологические проблемы Севера". Часть 1. [Abstracts: X Vsesoyuznyj sumpozium "Briologicheskie problemy Severa"] Магадан [Magadan]: 45.

[AFONINA, O.M. \& J. DUDA] АФОНИНА О.М., Й. ДУДА. 1983. Материалы к флоре печеночных мхов бассейна реки Анадырь. - [Contributions to the liverwort flora of the Anadyr River Basin] Новости сист. низш. pacm. [Novosti Sist. Nizsh. Rast.] 20: 182-190.

[AFONINA, O.M.] АФОНИНА О.М. 1983. Дополнения к флоре листостебельных мхов Чукотского полуострова. 3. - [Additions to the moss flora of the Chukotka Peninsula. 3.] Новости сист. низи. pacm. [Novosti Sist. Nizsh. Rast.] 20: 180-182.

[AFONINA, O.M.] АФОНИНА О.М. 1984. Кампилиум Крылова: 449; Ореас Марциуса: 453; Плагиотециум тупейший: 460. В кн.: Красная книга СССР. Редкие и находящиеся под угрозой исчезновения виды животных и растений. T. 2. [In: Red Data Book of USSR. Vol. 2] M., Лесная пром-сть. [Moscow, "Lesnaya promyshlennost].

[AFONINA, O.M.] АФОНИНА О.М. 1985. О видах рода Schistidium на Чукотском полуострове. - [On species of the genus Schistidium from the Chukotka Peninsula] Новости сист. низш. pacm. [Novosti Sist. Nizsh. Rast.] 22: 214-223.

[ABRAMOVA, A.L., O.M. AFONINA \& J. DUDA] АБРАМOBA А.Л., О. М. АФОНИНА, Й. ДУДА. 1985. Печеночные мхи Чукотского полуострова. - [Liverworts of the Chukotka Peninsula] Магадан: ин-т биол. пробл. Севера [Magadan: institute biologii problem Severa]: 1-40.

[ABRAMOVA, A.L., O.M. AFONINA \& L.S. BLAGODATSKICH] АБРАМОВА А.Л., О.М. АФОНИНА, Л.С. БЛАГОДАТСКИХ. 1985. Oligotrichum falcatum Steere в CССР. - [Oligotrichum falcatum Steere in the USSR] Новости сист. низи. pacm. [Novosti Sist. Nizsh. Rast.] 22: 210-214.

OCHYRA, R. \& O.M. AFONINA. 1986. The taxonomic position and geographical distribution of Grimmia andreaopsis C. Muell. (Grimmiaceae, Musci). - Polish Polar Research. 7, 3: 319-332.

[AFONINA, O.M.] АФОНИНА О.М. 1986. Листостебельные мхи низовьев р. Индигирки. - [Mosses of the Lower Indigirka River] Новости сист. низш. pacm. [Novosti Sist. Nizsh. Rast.] 23: 215-222.

[AFONINA, O.M.] АФОНИНА О.М. 1986. Дополнения к флоре мхов Чукотского полуострова. 4. - [Additions to the moss flora of the Chukotka Peninsula. 4.] Новости сист. низш. pacm. [Novosti Sist. Nizsh. Rast.] 23: 222-228.

[ABRAMOVA, A.L., O.M. AFONINA \& J. DUDA] АБРАМОВА А.Л., О. М. АФОНИНА, Й. ДУДА. 1987. Экология и распространение печеночных мхов на Чукотском полуострове. [Ecology and distribution of the liverworts in the Chukotka Peninsula] В кн: Экология, распространение и жизненные формы растений Магаданской области [In: Ekologiya, rasprostronenie i zhiznennye formy rastenij Magadanskoj oblasti] Владивосток: ДВО АН СCCP. [Vladivostok, DVO AN USSR]: 54-65.

[AFONINA, O.M.] АФОНИНА О.М. 1987. Дополнения к флоре мхов Чукотского полуострова. 5. - [Additions to the moss flora of the Chukotka Peninsula. 5.] Новости сист. низш. pacm. [Novosti Sist. Nizsh. Rast.] 24: 189-192.

[AFONINA, O.M. \& J. DUDA] АФОНИНА О.М., Й. ДУДА. 1987. Материалы к флоре печеночных мхов бассейна р. Анадырь. 2. - [Materials to the liverwort flora of the Anadyr River' Basin. 2] Новости сист. низи. pacm. [Novosti Sist. Nizsh. Rast.] 24: 193-197.
[AFONINA, O.M.] АФОНИНА О.М. 1988. Листостебельные мхи Чукотского полуострова. Сем. Sphagnaceae-Splachnaceae. Ч. I. - [Mosses of the Chukotka Peninsula. Sphagnaceae-Splachnaceae. Part I] Магадан. [Magadan]: 1-42.

[AFONINA, O.M.] АФОНИНА О.М. 1988. Листостебельные мхи Чукотского полуострова. Сем. Bryaceae-Hypnaceae. Ч. II. [Mosses of the Chukotka Peninsula. Bryaceae-Hypnaceae. Part II] Магадан. [Magadan]: 1-47.

[AFONINA, O.М.] АФОНИНА О.М. 1988. Редкие виды листостебельных мхов Чукотского полуострова. - [Rare moss species of the Chukotka Peninsula] Тезисы докл.: Актуальные вопросы ботаники в СССР. VIII делегат. съезда ВБО. [Abstract: Actualnye voprosy botaniki v SSSR. VIII delegatskij s'epl VBO] Алма-Ama. [Alma-Ata]: 99-100.

[AFONINA, O.M. \& J. DUDA] АФОНИНА О.М., Й. ДУДА. 1988. Материалы к флоре печеночных мхов острова Врангеля. [Contributions to the liverwort flora of Wrangel Island] Hовости cист. низи. pacm. [Novosti Sist. Nizsh. Rast.] 25: 170-175.

[AFONINA, O.M.] АФОНИНА О.М. 1988. Кампилиум Крылова: 491-492; Ореас Марциуса: 495-496; Лептоптеригинандрум южно-альпийский: 505; Плагиотециум тупейший: 502-503; Фоссомброния аляскинская: 507-508; Нардия японская: 508. - В кн.: Красная книга РСФСР. Растения. [In: Red Data Book of RSFSR.] M., Росагропромиздат. [Moscow, Rosagropromizdat].

AFONINA, O.M., B. MURRAY. 1988. Conference of Bryological Section of the Scientific Council of the Academy of Sciences of the U.S.S.R. Dedicated to the 100th Anniversary of the Birth of L.I. Savich-Lyubitskaya. - Taxon. 37(2): 400-404.

AFONINA, O.M. 1989. The moss flora of the Chukotka Peninsula and its main features. - In: Proceedings of the Sixth Meeting of the Central and East European Bryological Working Group (CE$B W G)$, Lublice, Czechoslovakia, 12th through 16th September 1988. Publ.: Botanical Inst. of the Czechoslovak Academy of Sciences, Pruhonice: 21-28.

[AFONINA, O.М.] АФОНИНА О.М. 1989. Список листостебельных мхов Чукотского полуострова. - [List of mosses of the Chukotka Peninsula] В кн.: Проблемы бриологии в СССР. [In Problemy briologii v SSSR] Л.: Наука. [Leningrad, Nauka]: 5-29.

[AFONINA, O.M.] АФОНИНА О.М. 1989. Дополнения к флоре листостебельных мхов острова Врангеля. - [Additions to the moss flora of the Wrangel Island] В кн.: Водоросли, лишайники, грибы и мохообразные в заповедниках РСФСР. [In: Vodorosli, lishajniki, griby i mokhoobraznye v zapovednikakh RSFSR] $M$. [Moscow]: 114-118.

[AFONINA, O.M. \& J. DUDA] АФОНИНА О.М., Й. ДУДА. 1989. К флоре печеночных мхов северной Корякии. - [To the liverwort flora of the northern Korjakia] Новости сист. низи. раст. [Novosti Sist. Nizsh. Rast.] 26: 147-149.

[PULYAEV, A.I. \& O.M. AFONINA] ПУЛЯЕВ А.И., О.М. АФОНИНА. 1989. К флоре листостебельных мхов югозападной части о. Врангеля. - [То the moss flora of the southwest Wrangel Island] $В$ кн.: Водоросли, лишайники, грибы и мохообразные в заповедниках РСФСР. [In: Vodorosli, lishajniki, griby i mokhoobraznye v zapovednikakh RSFSR] M. [Moscow]: 106-113.

[ABRAMOV, I.I. \& O.M. AFONINA] АБРАМОВ, И.И., О.М. АФОНИНА 1990. О перспективах бриологических исследований в CCCP. - [On prospects of the bryological investigations in the USSR]. Ботаника. Исследования [Botanika. Issledovaniya] Минск [Minsk] 30: 12-18.

[AFONINA, O.M.] АФОНИНА О.М. 1990. К флоре листостебельных мхов бассейна р. Анадырь. - [To the moss flora of 
the Anadyr River Basin]. Новости сист. низш. pacm. [Novosti Sist. Nizsh. Rast.] 27: 126-128.

AFONINA, O.M. \& R.N. SCHLJAKOV. 1990. Russian Version compilation. "Glossarium polyglottum bryologiae" ed. R.E. Magill. Missouri Bot. Gard.: 215-246.

AFONINA, O.M. 1990. Bryoflora of Chukotka and the ways of its formation. - Abstract of report at the Congress of the East Asiatic Bryology. August 12-19, Helsinki: 9.

[AFON1NA, O.M., N.A. KONSTANTINOVA \& I.V. CZERNYADJEVA] АФОНИНА О.М., Н.А. КОНСТАНТИНОВА, И.В. ЧЕРНЯДЬЕВА. 1990. Каталог литературы по мохообразным, опубликованной в СССР. 1986-1989. - [Catalogue of literature on bryophytes published in the USSR. 1986-1989]. Anamumbl, АН СССР, КНЦ, Полярно-Альп. Бот. Сад [Apatity, Akad Nauk SSSR, KoL Nauchn. Zentr., Polarno-Alp. Bot. Sad]: 1-51.

AFONINA, O.M. \& N.A. KONSTANTINOVA. 1990. Current bryofloristic exploration of the North of the USSR. - In: Schljakov, R.N. (ed.) Abstracts of the Seventh Meeting of the Central and East European BryologicalnWorking Group. Kirovsk- Apatity, 25-30 June 1990. Apatity, Acad. Sci. USSR, Kola Sci. Center, Polar-Alpine Bot. Garden: 4-5.

KOPONEN, T. \& O. AFONINA. 1990. Miscellaneous notes on Mniaceae (Bryophyta) XV. Genus Rhizomnium in the USSR, East of Ural Mts. - Abstract of report at the Congress of the East Asiatic Bryology. Helsinki, August 12-19, 1990.

KOPONEN, T. \& O. AFONINA. 1992. Miscellaneous notes on Mniaceae (Bryophuta) XV. Genus Rhizomnium in the Russia East of Ural Mts. - Proceedings of the Congress of East Asiatic Bryology, Helsinki, August 12-19, 1990. Bryobrothera 1: 245-250.

[AFONINA, O.M. \& J. DUDA] АФОНИНА О.М., Й. ДУДА. 1992. К флоре печеночных мхов центральной и западной Чукотки. - [On the hepatic flora of the Central and Western Chukotka]. Новости сист. низи. pacm. [Novosti Sist. Nizsh. Rast] 28: 140-144.

IGNATOV, M.S. \& O.M. AFONINA (eds.). 1992. Check-list of mosses of the former USSR. - Arctoa 1(1-2): 1-85.

[AFONINA, О.M. \& J. DUDA] АФОНИНА О.М., Й. ДУДА. 1993. Печеночные мхи Чукотки. - [Liverworts of the Chukotka] Бот. Журн. [Bot. Zhurn.] 78(3): 77-93.

[ANDREEV, M.P., O.M. AFONINA \& A.D. POTEMKIN] АНДРЕЕВ, М.П., О.М. АФОНИНА, А.Д. ПОТЕМКИН. 1993. Мохообразные и лишайники островов Комсомолец и Большевик (Архипелаг Северная Земля). - [Bryophytes and lichens of the Komsomolets and Bolshevik Islands (The Severnaya Zemlya Archipelago)] Бот. Журн. [Bot. Zhurn.] 78(2): 69-79.

[AFONINA, O.M. \& E.N. ANDREEVA] АФОНИНА O.M., Е.Н. АНДРЕЕВА. 1993. О нахождении спорогонов мха Lyellia aspera (Hag. et C. Jens.) Frye. - [About finding of the sporophytes of Lyellia aspera (Hag. et C. Jens.) Frye] Новости сист. низи. pacm. [Novosti Sist. Nizch. Rast.] 29: 132-138.

DEMBITSKI, V.M., T. REZANKA, I.A. BYCHEK \& O.M. AFONINA. 1993. Acetylenic acids and lipid compositions of some mosses from Russia. - Phytochemistry. 33(5): 1021-1027.

DEMBITSKI, V.M., T. REZANKA, I.A. BYCHEK \& O.M. AFONINA. 1993. Polar lipid and fatty composition of some bryophytes. - Phytochemistry. 33( 5): 1009-1014.

[AFONINA, O.M.] АФОНИНА О.М. 1994. Заметки о мхах Чукотки 1. Виды рода Pohlia (Bryaceae) с выводковыми почками. - [Notes on mosses of the Chukotka. 1. Propaguliferous species of the genus Pohlia (Bryaceae)] Бот. Журн. [Bot. Zhurn.] 79(2): 102-105.

[AFONINA, O.M. \& N.A. SEKRETAREVA] АФОНИНA O.M., Н.А. СЕКРЕТАРЕВА. 1994. Мхи ивовых кустарниковых и тундровых сообществ верхнего течения реки Неизвестной (остров Врангеля). - [The mosses of the willow shrub and tundra communities in the Upper Neizvestnaya River, Wrangel Island] Бот. Журн. [Bot. Zhurn.] 79(7): 43-52.

[AFONINA, O.M. \& R. OCHYRA] АФОНИНА О.М., Р. ОХЫРА 1994. Schistidium cryptocarpum (Musci, Grimmiaceae) - новый вид для Евразии. - [Schistidium cryptocarpum (Musci, Grimmiaceae) - a species new to Eurasia] Бот. Журн. [Bot. Zhurn.] 79(10): 128-133.

[AFONINA, O.M.] АФОНИНА О.М. 1994. Флора окрестностей бухты Сомнительной: мохообразные. - [Flora of the vicinities of Somnitelnaya Bay: bryophytes.] В кн: Арктические тундры острова Врангеля (Материаль ботанического полустачионара "Бухта Сомнительная" 1984-1988 гг.) (ред. Б. А. Юрuев). [In: B. A. Yurtsev (ed.) Arcticheskie tundry ostrova Vrangelya (Materialy botanicheskogo polustatsionara "Bukhta Somnitelnaya”, 1984-1988) СПб., РАН, Бот. Ин-т им. В. Л. Комарова. [St. Petersburg, Bot. Inst. Russ. Acad. Sci.]: 66-90.

[KOZHEVNIKOV, Yu.P., M.P. ZHURBENKO \& O.M. AFONINA] КОЖЕВНИКОВ Ю.П., М.П. ЖУРБЕНКО, О.М. АФОНИНА. 1994. Растительный покров островов Свердруп и Тройной (Карское море). - [Vegetation of Trynoy and Sverdrup Islands (Kara Sea)] В кн.: Арктические тундры Таймыра и островов Карского моря (ред. Э. В. Рогачева) [In: Rogacheva, E. V. (ed.) Arcticheskie tundry Tajmyra i ostrovov Karskogo тогуа] Москва, РАН, Институт проблем экологии и эволюиии и др. [Moscow, Inst. Problem Ekol. i Evol. Ross. Akad. Nauk \& al.] 2: 121-143.

DEMBITSI, V.M., T. REZANKA, I.A. BYCHEK \& O.M. AFONINA. 1994. Chemical constituents of some moss species. - J. Hattori Bot. Lab. 75: 161-172.

AFONINA O.M. 1995. Ivan Ivanovich Abramov (1912 - 1990). Arctoa 4: 105-117.

[AFONINA, O.M.] АФОНИНА О.М. 1995. Интересные находки листостебельных мхов на Чукотке. - [Interesting findings of mosses in Chukotka] Новости сист. низш. pacm. [Novosti Sist. Nizch. Rast.] 30: 93-97.

OCHYRA, R. \& O.M. AFONINA. 1995. Schistidium cryptocarpum (Musci, Grimmiaceae) in the Russian Arctic. - Fragm. Flor. Geobot. 40(1): 215-221.

AFONINA, O.M. [АФОНИНА О.М.] 1995. Эксикаты мохообразных России и сопредельных государств. - [Bryophyta Rossica et civitatum collimitanearum] СПб., БИН РАН [SanktPetersburg, Bot. Inst. Russ. Acad. Sci.] 1(№ 1-25): 1-19; 2(№ 26-50): 1-10; 3(№ 51-75): 1-10; 4(№ 76-100): 1-10.

AFONINA, O.M. \& I.V. CZERNYADJEVA. 1995. Mosses of the Russian Arctic: checklist and bibliography. - Arctoa 5: 99-142.

AFONINA, O.M. \& I.V. CZERNYADJEVA. 1995. Rare mosses of the Russian Arctic. - Abstract. VI International Symposium IOPB (International Organization of Plant Biosystematists) "Variation and Evolution in Arctic and Alpaine Plants", Tromso, Norway, July 29-August 2, 1995: 29.

AFONINA, O.M. \& I.V. CZERNYADJEVA. 1996. A brief historical survey of moss studies in the Russian Arctic. -Fragm. Flor. Geobot. 41(2): 827-843.

[AFONINA, O.M. \& I.V. CZERNYADJEVA] АФОНИНА O.M., И.В. ЧЕРНЯДЬЕВА. 1996. Итоги изучения флоры листостебельных мхов Русской Арктики. - [The results of investigation of moss flora of the Russian Arctic] Новости сист. низш. pacm. [Novosti Sist. Nizsh. Rast.] 31: 151-167.

[SAMARSKIJ, M.A., M.V. SOKOLOVA, M.P. ZHYRBENKO \& O.M. AFONINA] САМАРСКИЙ М.А., М.В. СОКОЛОВА, М.П ЖУРБЕНКО, О.М. АФОНИНА. 1997. О флоре и растительности острова Жохова, Новосибирские острова. - [On the flo- 
ra and vegetation of the Zhokhov Island, Novosibirskiye Islands] Бот. Журн. [Bot. Zhurn.] 82(4): 62-70.

[KUVAEAV, V.B., O.M. AFONINA, M.P. ZURBENKO, M.V. MELNIKOV \& F.A. ROMANENKO] KУBAEB, В.Б., O.M. АФОНИНА, М.П. ЖУРБЕНКО, М.В. МЕЛЬНИКОВ, Ф.А. РОМАНЕНКО. 1997. Растительный покров острова Русского (Архипелаг Норденшельда, Карское море). - [The plant cover of the Russkiy Island (the Kara Sea, Nordenskjold's Archipelago)] Бom. Журн. [Bot. Zhurn.] 82(10): 100-111.

[AFONINA, O.M. \& K.K. KRIVOSHAPKIN] АФОНИНА O.M., К.К. КРИВОШАПКИН. 1998. О новой находке Myurella acuminata Lindb. et H. Arnell в Якутии. - [On the new record of Myurella acuminata Lindb. et H. Arnell in Yakutiya] Новости cucm. низи. pacm. [Novosti Sist. Nizsh. Rast.] 32: 131-135.

AFONINA, O.M. \& I.V. CZERNYADJEVA. 1998. New records of Encalypta mutica Hag. (Encalyptaceae, Musci) in Russia. - Lindbergia 23: 107-109.

AFONINA, O.M. \& Н. ANDO [АФОНИНА О.М., Х.АНДО]. 1998. Hурпит holmenii (Hypnaceae) in Russia. - В кн.: Проблемь ботаники на рубеже XX-XXI веков. Тез. док., представленных II(X) съезду Русского ботанического общества (26-29 мая 1998, Санкт-Петербург). T. 2. [In: Problems of the botanical sciences at the boundary of XX and XXI centuries: Abstract, presented to the II $(X)$ Congress of the Russian Botanical Society (26-29 May, 1998, St. Peterburg). Vol. 2] СПб, Ботанический ин-m PAH [St. Petersburg, Komarov Botanical Institute]: 126-127.

AFONINA, O.M. 1998. The most important bryiophyte collections in the Botanical Institutions of Russia. - In: Stuchlik, L. (ed.) Botanical collections throughout the world. Proceedings of $2 d$ Int. Conf. on the preservation of botanical collections. Cracow, June 26-29, 1997. Krakow: 49-53.

[AFONINA, O.М.] АФОНИНА О.М. 1999. К флоре листостебельных мхов острова Большевик (архипелаг Северная Земля). [On the moss flora of Bol'shevik Island (Severnaya Zenlya)] Новости сист. низи. pacm. [Novosti Sist. Nizch. Rast.] 33: 171-179.

[AFONINA, O.M. \& I.B. KUCHEROV] АФОНИНА О.М., И.Б. КУЧЕРОВ. 1999. Флора листостебельных мхов внутренней части перешейка Чукотского полуострова (Район Амгуэмского моста). - [Moss flora of the inner part of isthmus of the Chukchi Peninsula (the vicinities of the Amguema Bridge) Бот. Журн. [Bot. Zhurn] 84(5): 77-95.

WU, PENG-CHENG \& O.M. AFONINA. 1999. A preliminary list of the mosses of Xinjiang at the herbarium of Institute of Botany, Academia Sinica (PE). - Chenia, Contributions to the Cryptogamic Biology. 6: 115-118.

[AFONINA, O.M. \& H. ANDO] АФОНИНА О.М., Х. АНДО. 2000. Hypnum holmenii (Musci, Hypnaceae) в бриофлоре России. [Hypnum holmenii (Musci, Hypnaceae) in moss flora of Russia] Бот. Журн. [Bot. Zhurn] 85(3): 40-46.

[AFONINA, O.M.] АФОНИНА О.М. 2000. Мохообразные. [Bryophytes] Флора и фауна заповедников. Bып. 88. Мохообразные и лишайники заповедника «Остров Врангеля». [Flora ifauna zapovednikov. 88. Mochoobraznye i lishajniki zapovednika "Ostrov Vrangelya"] M. [Moscow]: 6-46.

[AFONINA, O.M.] АФОНИНА О.М. 2000. Арктический элемент во флоре мхов Чукотки. - [The arctic element in moss flora of Chukotka] B кн.: Микология и криптогамная ботаника в России: традици и современность. Тр. междунар. конф., посвященной 100-летию организации исследований по микологии и криптогамной ботанике в Ботаническом ин-те им. В.Л. Комарова РАН (Санкт-Петербург, 24-28 апреля, 2000 2.) [In: Mikologia i kriptogamnaya botanika v Rissii: traditzii $i$ sovremennost' (Proc. konf., Sankt-Petersburg, 24-28 April, 2000)] СПб. [St. Petersburg]: 490-492.
[AFONINA, O.M.] АФОНИНА О.М. 2000. Становление и развитие бриологии в Ботаническом институте им. В.Л. Комарова РАH. - [Development of bryology in the Komarov Botanical Institute RAS] В кн.: Микология и криптогамная ботаника в России: традиции и современность. Тр. междунар. конф., посвященной 100-летию организации исследований по микологии и криптогамной ботанике в Ботаническом ин-те им. В.Л. Комарова РАН (Санкт-Петербург, 24-28 апреля, 2000 г.) [In: Mikologia i kriptogamnaya botanika v Rissii: traditzii i sovremennost' (Proc. konf., Saint Petersburg, 24-28 April, 2000)] CПб. [St. Petersburg]: 39-46.

[AFONINA, O.M., E.N. ANDREEVA, L.E. KURBATOVA \& A.D POTЕМКIN] АФОНИНА О.М., Е.Н. АНДРЕЕВА, Л.Е. КУРБАТОВА, А.Д. ПОТЕМКИН. 2000. Мохообразные (Bryophyta). - [Bryophytes] В кн.: Красная книга природы Ленинградской области. Растения и грибы. T. 2 [In: Red data book of Leningrad region. Plants and Fungi. Sankt-Petersburg. 2] СПб. [St. Petersburg]: 295-358.

[AFONINA, O.М.] АФОНИНА О.М. 2001. Зональное распределение мхов в тундрах Чукотки и Архипелага Северная Земля. [Zonal distribution of mosses in tundras of the Chukotka and the Severnaya Zemlya Archipelago] В кн.: Проблемы сохранения биоразнообразия в наземных и морских экосистемах севера. Тез. док. международной конф. и выездной сессии Отделения общей биологии РАН, 27-31 августа 2001 г., Апатиты [In: Problems of biodiversity preservation in ground and marine ecosysrems in the north. Abstracts International conference and guest session of the department of the general biology of the Russian Academy of Sciences, 26-31 August, Apatity] Anamumbl [Apatity]: 7-8.

[AFONINA, O.M.] АФОНИНА О.М. 2002. Дополнения к флоре мхов архипелага Северная Земля. - [Additions to the moss flora of the Severnaya Zenlya Archipelago] Новости сист. низш. pacm. [Novosti Sist. Nizch. Rast.] 36: 203-210.

[AFONINA, O.M.] АФОНИНА О.М. 2002. Научный вклад И.И. Абрамова в развитие отечественной бриологии. - [Scientific contribution of I.I. Abramov to native bryology] В кн.: Проблемы бриологии на рубеже веков. Материалы международного совещания, посвященного 90-летию со дня рождения Романа Николаевича Шлякова (20.06.1912) и Ивана Ивановича Абрамова (14.07.1912), Санкт-Петербург, 4-6 ноября 2002 г. [In: Problems of bryology at the boundary of centries. Proceedings of the international conference devoted to 90-th anniversary of R.N. Schljakov (20.06.1912) and I.I. Abramov (14.07.1912), Saint Petersburg, November 4-6, 2002] СПб [St. Petersburg]: 7-13.

[AFONINA, O.M. \& N.V. MATVEEVA] АФОНИНА О.M., Н.В. MATBEEBA. 2002. Особенности флоры мхов полярных пустынь на примере острова Большевик (архипелаг Северная Земля). - [Peculiarities of moss flora of Polar Deserts (the case of Bolshevik Island, Severnaya Zemlya Archipelago] В кн.: Проблема бриологии на рубеже веков. Материалы международного совещзания, посвященного 90-летию со дня рождения Романа Николаевича Шлякова (20.06.1912) и Ивана Ивановича Абрамова (14.07.1912), Санкт-Петербург, 4-6 ноября 20022. [In: Problems of bryology at the boundary of centries. Proceedings of the international conference devoted to 90-th anniversary of R.N. Schljakov (20.06.1912) and I.I. Abramov(14.07.1912), Saint Petersburg, November 4-6, 2002] СПб [St. Petersburg]: 15-17.

[AFONINA, O.M. \& N.V. MATVEEVA] АФОНИНА О.М., Н.В. MATBEEBA. 2003. Мхи острова Большевик (архипелаг Северная Земля). - [Mosses of the Bolschevik Island (Severnaya Zemlya Archipelago)] Бот. Журн. [Bot. Zhurn.] 88(9): 1-24.

IGNATOVA, E., H. BEDNAREK-OCHYRA, O. AFONINA \& J. MUÑOZ. 2003. A new species of Grimmia (Grimmiaceae, Musci) from North-East Asia and Alaska. - Arctoa 12: 1-8. 
[AFONINA, O.M.] АФОНИНА О.М. 2004. Дополнения к флоре мхов мыса Челюскин (полуостров Таймыр). - [Additions to the moss flora of Cape of Chelyuskin (Taimyr Peninsula)] Бom. Журн. [Bot. Zhurn.] 89(10): 1612-1616.

[AFONINA, O.M.] АФОНИНА О.М. 2004. Конспект флоры мхов Чукотки. - [Moss flora of Chukotka] CПб [St. Petersburg]: $260 \mathrm{pp}$

[ANDREEVA, E.N., O.M. AFONINA \& L.E. KURBATOVA] АНДРЕЕВА Е.Н., О.М. АФОНИНА, Л.Е. КУРБАТОВА. 2004. Мохообразные. - [Bryophytes] Красная книга СанктПетербурга [Red Data Book of Sankt-Petersburg] CПб. [St. Petersburg]: 325-342.

[AFONINA, O.M.] АФОНИНА О.М. 2004. Виды Нурпит секции Hamulosa (Musci, Hypnaceae) в России. - [The Hypnum sect. Hamulosa (Musci, Hypnaceae) in Russia] Arctoa 13: 9-28.

[AFONINA, O.M., I.V. CZERNYADJEVA, G.Ya. DOROSHINAUKRAINSKAJA, L.E. KURBATOVA \& E.Ju. KUZMINA] АФОНИНА О.М., И.В. ЧЕРНЯДЬЕВА, Г.Я. ДОРОШИНАУКРАИНСКАЯ, Л.Е. КУРБАТОВА, Е.Ю. КУЗЬМИНА. 2004. Эксикаты мохообразных России и сопредельных государств. Часть V. - [Bryophyta Rossica et civitatum collimitanearum exsiccate] CПб [St. Petersburg]: 1-28.

[AFONINA, O.M. \& T.K. YURKOVSKAYA] АФОНИНA O.M., T.К. ЮРКОВСКАЯ. 2005. C. Cortini Pedrotti. Flora dei muschi d"Italia. Roma, 2001. 817 P. + XII. (К. Кортини Педротти. Флора мхов Италии. Рим, 2001. 817 С. + ХІІ) Бот. журн. [Bot. Zhurn.]. 89(11): 138-140.

AFONINA, O. M., M.K. RAYNOLDS \& D.A. WALKER. 2005. On the moss flora of Mould Bay (Prince Patrick Island, Canadian Arctic Archipelago). - Arctoa 14: 135-142.

[AFONINA, O.M. \& L.I. ABRAMOVA] АФОНИНА О.М., Л.И. АБРАМОВА. 2005. Анастасия Лаврентьевна Абрамова (к 90летию со дня рождения). - [Anastasija Lavrent'evna Abramova (on the 90-years anniversary)] Бот. журн. [Bot. Zhurn.] 90(12): 1926-1939.

[AFONINA, O.M. \& L.S. BLAGODATSTKIH] АФОНИНА O.M., Л.С. БЛАГОДАТСКИХ. 2005. Мхи охраняемых природных территорий Оренбургской области. - [Mosses of the protected natural areas of the Orenburg Province]. В кн.: Актуальные проблемы бриологии, Тр. междунар. совещания, посв. 90летию со дня рожд. А.Л. Абрамовой. Санкт-Петербург, 2225 ноября 2005. [Proc. Int. Conf. "Actual Problems of Bryology" devoted to $90^{\text {th }}$ Anniversary of A.L. Abramova. St. Petersburg, 22-25 November 2005] СПб [St. Petersburg]: 13-19.

[CZERNYADJEVA, I.V. \& O.M. AFONINA] ЧЕРНЯДЬЕВА И.В., О.М. АФОНИНА. 2005. Мхи окрестностей пос. Пущино (Центральная Камчатка). - [Mosses of the vicinity of the Puschino Settlement (Central Kamchatka)] В кн.: Актуальные проблемы бриологии, Тр. междунар. совещания, посв. 90летию со дня рожд. А.Л. Абрамовой. Санкт-Петербург, 2225 ноября 2005. [Proc. Int. Conf. "Actual Problems of Bryology" devoted to $90^{\text {th }}$ Anniversary of A.L. Abramova. St. Petersburg, 22-25 November 2005] CПб [St. Petersburg]: 191-198.

AFONINA, O.M. 2006. New moss records from Nenetskij Autonomous District. 1. - Arctoa 15: 251.

AFONINA, O.M. 2006. New moss records from Chukotskij Autonomus District. 1. - Arctoa 15: 270.

[AFONINA, O.M.] АФОНИНА О.М. 2006. Мхи. - [Mosses] Красная Книга Ненеикого Автономного Округа. [Red Red Data Book of Nenetskiy Autonomous District]. Нарьян-Mар [Nar'yan-Mar]: 118-125.

AFONINA, O.M. \& L.S. BLAGODATSKIKH. 2006. New moss records from Magadan Province. 1. - Arctoa 15: 268.
[AFONINA, O.M. \& T.M. KOROLEVA] АФОНИНA O.M., T.M. КОРОЛЕВА. 2006. Мхи острова Четырехстолбового (архипелаг Медвежьи Острова, Восточно-Сибирское море). - [Mosses of the Chetyryokhstolbovy Island (Medvezhii Islands Archipelago, the East-Siberian Sea)] Новости сист. низи. раст. [Novosti Sist. Nizsh. Rast.) 40: 294-306.

[AFONINA, O.M., E.A. IGNATOVA \& A.I. MAKSIMOV] АФОНИНА О.М., Е.А. ИГНАТОВА, А.И. МАКСИМОВ. 2006. Stereodon fertilis (Pylaisiaceae, Musci) в России. - [Stereodon fertilis (Pylaisiaceae, Musci) in Rissia] Бот. журн. [Bot. Zhurn.] 91(2): 329-335.

IGNATOV, M.S., O.M. AFONINA, E.A. IGNATOVA et al. 2006. Check-list of mosses of East Eourope and North Asia. - Arctoa 15: $1-130$

BLOM, H.H., E.A. IGNATOVA \& O.M. AFONINA. 2006. New records of Schistidium (Grimmiaceae, Musci) in Russia. - Arctoa 15: 187-194.

[BELIKOVICH, A.V., A.V. GALANIN, O.M. AFONINA \& I.I. MAKAROVA ] БЕЛИКОВИЧ А.В., А.В. ГАЛАНИН, О.М. АФОНИНА, И.И. МАКАРОВА. 2006. Растительный мир особо охраняемых территорий Чукотки. - [Vegetation of Chukotka protected areas] Владивосток [Vladivostok]: 1-250.

[AFONINA, O.M., V.I. ZOLOTOV \& A.A. NOTOV] АФОНИНА О.М., В.И. ЗОЛОТОВ, А.А. НОТОВ. 2006. К флоре мхов Оренбургского государственного природного заповедника. [To moss flora of Orenburg State Nature Reserve] Cmenu Северной Евразии. Материаль IV международного симпозиума. [Stepi Severnoj Evrazii. Materialy IV mezhdunarodnogo simpoziuma] Оренбург: ИПК «Газпромпечать»ООО «Оренбурггазпромсервис» [Orenburg “Gazprompechat”'ОOО “Orenburggazpromservis”]: 71-75.

[POTEMKIN, A.D. \& O.M. AFONINA] ПОТЕМКИН А.Д., О.М. АФОНИНА. 2006. Рецензия. [Review] Z. Iwatsuki, H. Deguchi, T. Furuki. Mosses and Liverworts of Japan. Tokio, 2001. 355 P. 192 plates of color photographs. - Бот. Журн. [Bot. Zhurn.] 91(7): 1138-1140.

[AFONINA, O.M., I.V. CZERNYADJEVA \& L.E. KURBATOVA] АФОНИНА О.М., И.В. ЧЕРНЯДЬЕВА, Л.Е. КУРБАТОВА. 2006. Эксикаты мохообразных России и сопредельных государств. Ч. VI. - [Bryophyta Rossica et Civitatum collimitanearum exsiccate. F. VI] Cnб. [St. Petersburg]: 1-16.

[AFONINA, O.M.] АФОНИНА О.М. 2007. Флора мохообразных Пушкинского Заповедника. - [Moss flora of Pushkinckiy Reserve] В кн.: Михайловская пушкиниана. Вып. 43. Природанаш кабинет (результаты ботанических исследований 20032005 годов) [In: Mihajlovskaya pushkiniana. Vup. 43. Priroda - nash cabinet (rezul taty botanicheskih issledovanij 2003-2005)] Сельио Михайловское. [Sel'co Mihajlovskoe]: 219-233.

[AFONINA, O.M. \& V.Ya. CHERDANTSEVA] АФОНИНА O.M., В.Я. ЧЕРДАНЦЕВА. 2007. Stereodon calcicola (Pylaisiaceae, Musci) - новый вид во флоре мхов России. - [Stereodon calcicola (Pylaisiaceae, Musci) - new species for the moss flora of Russia] Бот. журн. [Bot. Zhurn.] 92(11): 1760-1763.

[AFONINA, O.M.] АФОНИНА О.М. 2007. К флоре мхов заказника "Горная степь". - [Tо the moss flora of preserve "Mountain Steppe"] В кн.: Растительный и животный мир трансграничной особо охраняемой территории. Труды Сохондинского заповедника. Bыn. 2. [In: Rastitel'nyj i zhivotmyj mit transgranichnoj osobo okhrantaemoj territorii. Trudy Sokhondinskogo zapovednika. Vyp. 2] Чuта, "Поиск” [Chita, "Poisk"]: 24-33.

[AFONINA, O.M.] АФОНИНА О.М. 2007. Новые находки мхов в Забайкальском крае. 1. - [New moss records from Zabaikal- 
sky Territory. 1] Arctoa 16: 197-198.

AFONINA, O.M. \& E.A. IGNATOVA. 2007. East Asian species of genus Stereodon (Brid.) Mitt.(Pylaisiaceae, Musci) in Russia. Arctoa 16: 7-20.

AFONINA, O., H. TSUBOTA \& E. IGNATOVA. 2007. The genus Pylaisiadelpha (Phylaisiadelphaceae, Musci) in Russia. - Arctoa 16: $127-132$.

AFONINA, O.M. \& E.A. IGNATOVA. 2007. A new species of Didymodon (Pottiaceae, Musci) from Asian Russia. - Arctoa 16: $133-138$.

[POTEMKIN, A.D. \& O.M. AFONINA] ПОТЕМКИН А.Д., О.М. АФОНИНА. 2007. Новые находки печеночников в Забайкальском крае. 1. - [New liverwort records from Zabaikalsky Territory. 1] Arctoa 16: 199.

[NOTOV, A.A., A.D. POTEMKIN \& O.M. AFONINA] HOTOB А.А., А.Д. ПОТЕМКИН, О.М. АФОНИНА. 2007. Новые находки мохообразных в Оренбургской области. 1. - [New bryophyte records from Orenburg Province. 1.] Arctoa 16: 189-190.

[AFONINA, O.M., O.V. LAVRINENKO \& N.V. MATVEJEVA] АФОНИНА О.М., О.В. ЛАВРИНЕНКО, Н.В. МАТВЕЕВА. 2007. К флоре мхов арктической части Ненецкого автономного округа. - [To the moss flora of arctic part of the Nenets autonomus area]. Новости сист. низи. pacm. [Novosti Sist. Nizsh. Rast.] 41: 281-302.

[AFONINA, O.M., I.V. CZERNYADJEVA, L.E. KURBATOVA \& Е.Ju. KUZMINA] АФОНИНА О.М., И.В. ЧЕРНЯДЬЕВА, Л.Е. КУРБАТОВА. 2007. Эксикаты мохообразных России и сопредельных государств. Часть VII. (№№ 251-280). - [Bryophyta Rossica et Civitatum collimitanearum exsiccate. F. VII, NN 251-280] СПб. [St. Petersburg]: 1-14.

IGNATOV, M., O. AFONINA \& E. IGNATOVA. 2007. Moss Diversity in Asian Russia. - World conference of bryology. 23-27 July 2007, Crystal Crown Hotel. Petaling, Jaya, Malaysia: 58.

[AFONINA, O.M.] АФОНИНА О.М. 2008. Мхи национального парка «Алханай» (Забайкальский край). - [Mosses of the “Alkhanai" national park (Zabaikalsky Territory)] Бот. журн. [Bot. Zhurn.] 93(12): 1878-1896.

[AFONINA, O.М.] АФОНИНА О.М. 2008. К флоре мхов Бурятии. - [To the moss flora of Buryatia] Новости сист. низи. pacm. [Novosti Sist. Nizsh. Rast.] 42: 225-234.

[AFONINA, O.M.] АФОНИНА О.М. 2008. О некоторых особенностях флоры мхов Забайкальского края. - [On some peculiarities of moss flora of Zabaikalsky Territory] $В \kappa н$ : Фундаментальные и прикладные проблемы ботаники в начале XXI века. Материалы Всероссийской конференции (Петрозаводск, 22-27 сентября 2008 г.). Часть 2. Альгология, микология, лихенология, бриология. [Fundamental'nye $i$ prikladnye problemy botaniki $v$ nachale XXI veka. Materialy Vserossiyskoj konferentcii (Petrozavodsk, 22-27 September 2008). Chast' 2. Al'gologiaya, Mikologiya, Likhenologiya, Briologiya] Петрозаводск [Petrozavodsk]: 275-277.

AFONINA, O.M., O.V. LAVRINENKO, S.S. KHOLOD \& I.A. LAVRINENKO. 2008. New moss records from Nenets Autonomous District. 2. - Arctoa 17: 192-194.

[IGNATOV, M.S., O.M. AFONINA \& E.A. IGNATOVA] ИГНАТОВ М.С., О.М. АФОНИНА, Е.А. ИГНАТОВА. 2008. Флора мхов России: состояние изученности и перспективы. - [The moss flora of Russia: the state of knowledge and prospects] $В к н$ : Фундаментальные и прикладные проблемы ботаники в начале XXI века. Материалы Всероссийской конференции (Петрозаводск, 22-27 сентября 2008 г.). Часть 2. Альгология, микология, лихенология, бриология. [Fundamental'nye $i$ prikladnye problemy botaniki v nachale XXI veka. Materialy Vse- rossiyskoj konferentcii (Petrozavodsk, 22-27 September 2008). Chast' 2. Al'gologiaya, Mikologiya, Likhenologiya, Briologiya[ Петрозаводск [Petrozavodsk]: 305-306.

[AFONINA, O.M.] АФОНИНА О.М. 2008. Stereodon. - Флора мхов России, http:Arctoa ru/Flora/taxonomy-ru/taxonomy-ru.php (версия 1.IX.2008).

[AFONINA, O.M., H. TSUBOTA \& E.A. IGNATOVA] АФОНИНА О.М., Х. ЦУБОТА, Е.А. ИГНАТОВА. 2008. Pylaisiadelpha.Флора мхов России, http:arctoa.ru/Flora/taxonomy-ru/taxonomyru.php (версия 1.IX.2008).

AFONINA, O.M., I.V.CZERNYADJEVA, M.V. DULIN, V.E. FEDOSOV, E.A. IGNATOVA, E.I. IVANOVA, S.G. KAZANOVSKY,Z.Kh KHARZINOV,A.I.MAKSIMOV,M.G.NAPREENKO,A.D.POTEMKIN, E.V. SOFRONOVA \& G.V.ZHELEZNOVA] АФОНИНA O.M., И.В. ЧЕРНЯДЬЕВА, М.В. ДУЛИН, В.Э. ФЕДОСОВ, Е.А. ИГНАТОВА, Е.И. ИВАНОВА, С.Г. КАЗАНОВСКИЙ, З.Х. ХАРЗИНОВ, А.И МАКСИМОВ, М.Г. НАПРЕЕНКО, А.Д. ПОТЕМКИН, Е.В. СОФРОНОВА, Г.В. ЖЕЛЕЗНОВА. 2008. Мохообразные. - [Bryophytes] В кн. Красная книга Российской Федерации (растения и грибы) / Министерство природных ресурсов и экологии РФ; Федеральная служба по надзору в сфере природопользования; РАН; Российское ботаническое общество; МГУ им. М.В. Ломоносова; Гл. редколл.: Ю.П. Трутнев и др.; Сост. P.B. Камелин и др. M.: KMK [In: Yu.P. Trutnev et al. (eds.) Krasnaya kniga Rossiijskoij Federatsii (rasteniya, griby) / Ministerstvo prirodnykh resursov i ekologii, Federal'naya sluzhba po nadzoru $v$ sfere prirodopolsovaniya; RAS; Rossiijskoe botanicheskoe obshchestvo; MGU im. M.V.Lomonosova] M. [Moscow]: 606-660.

[AFONINA, O.M. \& N.A. KONSTANTINOVA] АФОНИНА O.M., Н.А. КОНСТАНТИНОВА. 2008. Мохообразные. - [Bryophytes] В кн.: Красная книга Чукотского автономного округа. Том 2. Растения (ред. д.б.н., чл.-кор. РАН И.А. Черешнев) Издательский дом «Дикий Север». [In: Chereschnev, I.A. (ed.) Red Data Book of the Chukchi Autonomus District. Publishing house "Dikiy Sever"]: 125-165.

[AFONINA, O.M.] АФОНИНА О.М. 2008. Новые виды для флоры мхов Бурятии. - [New species for the moss flora of Buryatia] Бюлл. БСИ ДВО РАН [Электронный ресурс] науч. журн. / Ботан. Сад-институт ДВО PAH. [Byull. BSI DVO RAN] Владивосток. [Vladivostok] 1(2): 38-39.

POTEMKIN, A.D. \& O.M. AFONINA] ПОТЕМКИН А.Д., О.М. АФОНИНА. 2008. Новые находки печеночников в Забайкальском краe. 2. - [New liverwort records from Zabaikalsky Territory. 2] Arctoa 17: 218.

IGNATOV, M.S., O.M. AFONINA \& E.A. IGNATOVA. 2008. Moss Diversity in Asian Russia. - In: Mohamed, H., B.B. Baki, A. Nasrulhag-Boyce \& P.K.Y. Lee (eds.). Bryology in the New Millennium. Kuala Lumpur: University of Malaya: 157-164.

[AFONINA, O.M. \& E.A. IGNATOVA] АФОНИНА O.M., Е.A. ИГНАТОВА. 2009. Syntrichia amphidiacea (Pottiaceae, Bryophyta) - новый вид для флоры мхов России. - [Syntrichia amphidiacea (Pottiaceae, Bryophyta) - a new species for the moss flora of Russia] Бот. журн. [Bot. Zhurn.] 94(3): 439-443.

IGNATOV, M.S., E.A. IGNATOVA, O.M. AFONINA \& V.V. TELEGANOVA. 2009. Moss diversity in Russia: general overview and an analysis of the distribution of dioicous species. - In: S.I. Golovatch, O.L. Makarova, A.B. Babenko \& L.D. Penev (eds.) Spesies and Communities in Extreme Environments. Festschrift towards the $75^{\text {th }}$ Anniversary and a Laudatio in Honour of Academician Yuri Ivanovich Chernov. 2009. Sofia-Moscow. Pensoft Publishers \& KMK Scientific Press.: 319-334.

AFONINA, O.M. \& A. BREEN. 2009. Dicranum dispersum (Dicranaceae) and Sciuro-hypnum ornellanum (Brachytheciaceae), new to North America. - Bryologist 112(2): 268-272. 
[FEDOSOV, V.E. \& O.M. AFONINA] ФЕДОСОВ В.Э., О.М. АФОНИНА. 2009. Дополнения к флоре мхов урочища «АрыМас» (Западный Таймыр). - [Additions to the bryoflora of urochische "Ary-Mas" (East Taymyr)] Бот. журн. [Bot.Zhurn.] 94(9): 11-23

[AFONINA, O.M.] АФОНИНА О.М. 2009. Ryszard Ochyra, Ronald I., Lewis Smith and Halina Bednarek-Ochyra. The illustrated moss flora of Antarctica. Cambridge. 2008 + XVII. 685 Р. (Ришард Охыра, Рональд И. Льюис Смит и Галина Беднарек-Охыра. Иллюстрированная флора мхов Антарктики. Кембридж. 2008 + XVII. 685 C.). - Бот. журн. [Bot.Zhurn.] 94(12): 1743-1746.

AFONINA, O.M. 2009. On moss flora of Sokhondinski State Natural Biosphere Reserve (Zabaikalski Krai). - Arctoa 18: 141-150.

IGNATOVA, E.A., B.C. TAN, O.M. AFONINA \& M.S. IGNATOV. 2009. Sematophyllum (Sematophyllaceae, Bryophyta), a new genus and family for Russia - Arctoa 18: 213-216.

AFONINA, O.M. 2009. New moss records from Buryatia. 4. (East Sayan, upper of Oka River) - Arctoa 18: 273-274

AFONINA, O.M. 2009. New moss records from Mongolia. 1. - Arctoa 18: 281.

KONSTANTINOVA, N.A. \& O.M. AFONINA. 2009. New liverwort records from Zabaikal'sky Territory. 3. - Arctoa 18: 274-275.

[AFONINA, O.M. \& E.A. IGNATOVA] АФОНИНА O.M., Е.А. ИГНАТОВА. 2009. Hypnum fujiyamae (Hypnaceae, Bryophyta) - новый вид во флоре России с Курильских островов. - [Нypnum fujiyamae (Hypnaceae, Bryophyta), a new species for moss flora of Russia from Kuril Islands] Новости сист. низш. раст. [Novosti Sist. Nizch. Rast.] 43: 292-296.

AFONINA, O.M., I.V. CZERNYADJEVA, G.Ya. DOROSCHINA, L.E. KURBATOVA, E.Yu. KUZMINA \& D.Ya. TUBANOVA. 2009. Bryophyta Rossica et civitatum collimitanearum exsiccate. Fasciculus VIII (\#\# 281-350) CПб. [St. Petersburg]: 1-24.

[AFONINA, O.M. \& D.D. MITUPOVA] АФОНИНА О.М., Д.Д. МИТУПОВА. 2009. Разнообразие мхов. - [Mosses] В кн: Биологическое разнообразие начионального парка «Алханай»: результаты современных исследований/ Труды национального парка «Алханай». Bыn. 1. [In: Biologicheskoe raznoobrazie nacionalnogo parka "Alchanaj"/ Trudy nacionalnogo parka "Alchanaj". Vyp. 1.] Чuma [Chita]: 61-90.

[AFONINA, O. М.] АФОНИНА O.М. 2010. Вклад Зои Николаевны Смирновой в развитие бриологии. - [Contribution of Zoya Nikolaevna Smirnova in the development of bryology] $B$ кн.: Бриология: традиции и современность. Сборник статей по материалам международной бриологической конференции, посвященной 110-летию со дня рождения Зои Николаевны Смирновой иКлавдии Ивановны Ладыженской, СанктПетербург, 11-15 октября 2010 г. [In: Bryology: traditions and state-of-the-art. Proceedings of the international bryological conference devoted to the 110-th birthdays of Zoya Nikolaevna Smirnova and Claudia Ivanovna Ladyzhenskaja. Saint Petersburg, October 11-15, 2010] СПб [St. Petersburg]: 9-15.

OCHYRA, R. \& O. AFONINA. 2010. Schistidium frahmianum (Bryopsida, Grimmiaceae), a new arctic species from Beringia - Tropical Bryology. 31: 139-143.

[AFONINA, O.M., V.Ya. CHERDANTZEVA, E.A. IGNATOVA \& M.S. IGNATOV] АФОНИНА О.М., В.Я. ЧЕРДАНЦЕВА, Е.А. ИГНАТОВА, М.С. ИГНАТОВ. 2010. Symblephasis vaginata (Dicranaceae, Bryophyta) - новый род и вид для флоры мхов России. - [Symblephasis vaginata (Dicranaceae, Bryophyta) new genus and species for the moss flora of Russia] Бот. журн. [Bot. Zhurn.] 95(12): 1765-1770.

[AFONINA, O.M. \& D.Ya. TUBANOVA] АФОНИНА О.М., Д.Я. ТУБАНОВА. 2010. К флоре мхов юго-западной части Бурятии
(Восточный Саян). - [To moss flora of south-west part of Buryatia (East Sayan)] Новости сист. низш. pacm. [Novosti Sist. Nizch. Rast.] 44: 257-272.

AFONINA, O.M., I.V. CZERNYADJEVA, E.A. IGNATOVA \& J. KUČERA. 2010. Five species of Didymodon (Pottiaceae) new for Russia. - Arctoa 19: 51-62.

IGNATOVA, E.A. \& O.M. AFONINA. 2010. Ditrichopsis baikalensis (Ditrichaceae, Bryophyta), a new species from Asiatic Russia. - Arctoa 19: 51-62.

MAMONTOV, Yu.S., N.A. KONSTANTINOVA, O.M. AFONINA. 2010. New liverwort records from Zabaikal'sky Territory. 4. Arctoa 19: 275-277.

AFONINA, O.M., M.S. IGNATOV \& J. KUИERA. 2010. New moss records from Zabaikal'sky Territory. 2. - Arctoa 19: 277.

[AFONINA, O.M.] АФОНИНА О.М. 2011. Ксерофитные черты флоры мхов Забайкальского края. - [ Xerophyte characters of moss flora of Zabaikal'sky Territory] В кн.: Разнообразие почв и биоть Северной и Центральной Азии. [In: Raznoobrazie pochv i bioty Severnoi i Centralnoi Asii] Улан-Удэ [Ulan-Ude]: 171-173.

[AFONINA, O.M.] АФОНИНА О.М. 2011. Первая находка Leptodontium flexifolium (Pottiaceae, Bryophyta) в Арктической Аляске. - [The first record of Leptodontium flexifolium (Pottiaceae, Bryophyta) for Arctic Alaska] Новости сист. низш. раст. [Novosti Sist. Nizsh. Rast.] 45: 267-275.

MAMONTOV, Yu.S., N.A. KONSTANTINOVA \& O.M. AFONINA. 2011. New liverwort records from Zabaikal'sky Territory. 5. - Arctoa 20: 259-261.

AFONINA, O.M., E.A. IGNATOVA \& I.V. CZERNYADJEVA. 2011 New moss records from Zabaikal'sky Territory. 3. - Arctoa 20: 261-262.

[AFONINA, O.M.] АФОНИНА О.М. 2012. Дополнения к флоре мхов Сохондинского государственного природного биосферного заповедника (Забайкальский край). - [An addition to the moss flora of the Sokhondinsky State Nature Biosphere Reserve (Zabaikalsky territory)] В кн.: Растительный и животный мир трансграничной особо охраняемой территории: Труды Сохондинского заповедника. Bыn. 5. [In: Rastitel'nyj i zhivotnyi mir transgranichnoi osobo ohranyaemoi territorii. Trudy Sokhondinskogo zapovednika. Vyp. 5] Чuma [Chita]: 13-17.

AFONINA, O.M. 2012. Contribution of R.N. Schljakov to the study of moss flora of Russia. - Международная бриологическая конференщия, посвященная 100-летию со дня рождения Г.Н. Шлякова. Апатиты, Мурманская область, 24-26 июня 2012. Тезисы докладов. [In: International Bryological Conference dedicated to 100 year anniversary of R.N. Schljakov. Apatity, Murmansk Province, 24-26th June 2012. Abstracts]. Anamumbl [Apatity]: 9-11.

KUČERA, J., E.A. IGNATOVA \& O.M. AFONINA 2012. Didymodon giganteus (Pottiaceae, Bryophyta) in Chukotka - Новости сист. низи. pacm. [Novosti Sist. Nizsh. Rast.] 46: 274-278.

[AFONINA, O.M. \& V.Ya. CHERDANTSEVA] АФОНИНА O.M., В.Я. ЧЕРДАНЦЕВА 2012 O Drummondia sinensis var. ussuriensis (Drummondiaceae, Bryophyta). - [On Drummondia sinensis var. ussuriensis (Drummondiaceae, Bryophyta)] Новости сист. низи. pacm. [Novosti Sist. Nizsh. Rast.] 46: 235-244.

[AFONINA, O.M., E.A. IGNATOVA \& V.I. ZOLOTOV] АФОНИНА О.М., Е.А. ИГНАТОВА, В.И. ЗОЛОТОВ. 2012. Дополнения к флоре мхов Забайкальского края. - [The additions to the moss flora of Zabaikal'sky Territory] Бот. журн. [Bot. Zhurn.] 97(11): $1448-1451$ 
AFONINA, O.M. \& I.V. CZERNYADJEVA. 2012. New moss records from Zabaikal'sky Territory. 4. - Arctoa 21: 294.

IGNATOV, M.S., O.M. AFONINA, O.I. KUZNETSOVA \& E.I. IGNATOVA. 2012. The genus Leptopterigynandrum (Taxiphyllaceae, Dryophyta) in Russia. - Arctoa 21: 207-220.

AFONINA, O.M. \& I.V. CZERNYADJEVA. New moss records from Zabaikal'sky Territory. 4. - Arctoa 21: 207-220.

MAMONTOV, Yu.S. \& O.M. AFONINA. 2012. New liverwort records from Zabaikal'sky Territory. 6. - Arctoa 21: 290-294.

AFONINA, O.M. 2012. Contribution of R.N. Schljakov to the study of moss flora of Russia. - Abstracts: International Bryological conference dedicated to 100 year anniversary of R.N. Schljakov. Apatity, Murmansk Province 24-26 th June 2012] Anamumbl [Apatity]: 9-11.

AFONINA, O.M., I.V. CZERNYADJEVA \& E.Yu. KUZMINA. 2012. Bryophyta Rossica et civitatum collimitanearum exsiccate. Fasciculus VIII (\#\# 351-400) CПб. [St. Petersburg]: 1-20.

[AFONINA, O.M., Yu.S. MAMONTOV \& I.V. CZERNYADJEVA] АФОНИНА О.М., Ю.С. МАМОНТОВ, И.В. ЧЕРНЯДЬЕВА. 2012. Мхи и печеночники Сохондинского государственного заповедника. - [Mosses and liverworts of the Sokhondinsky State Reserve] СПб. [St. Petersburg]: 1-200.

WERNER, O., S. RAMS, J. KUČERA, J., LARRAÍN, O.M. AFONINA, S. PISA \& M.R. ROS. 2013. New data on the moss genus Hymenoloma, with special reference to H. mulahaceni. - Cryptogamie, Bryologie. 34: 1-18.

[AFONINA, O.M., Yu.S. MAMONTOV \& I.V. CZERNYADJEVA] АФОНИНА О.М., Ю.С. МАМОНТОВ, И.В. ЧЕРНЯДЬЕВА. 2013. Новые и редкие виды печеночников и мхов для Забайкальского края. - [New and rare the liverworts and mosses from Zabaikalsky Territory] Бот. журн. [Bot. Zhurn.] 98(11): 1427-1440

CZERNYADJEVA, I.V., Yu.S. MAMONTOV \& O.M. AFONINA. 2013. Contribution to bryophyte flora of Atsinskiy sanctuary (Zabaikal'sky Territoy, Southern Siberia). - Arctoa 22: 217-222.

AFONINA, O.M. \& E.A. IGNATOVA. 2013. Ditrichopsis clausa Broth. (Ditrichaceae, Musci), a new species for Russia. - Arctoa 22: 159-162.
[KONSTANTINOVA, N.A., O.M. AFONINA \& A.D. POTEMKIN] КОНСТАНТИНОВА Н.А., О.М. АФОНИНА, А.Д. ПОТЕМКИН. 2013. International Bryological Conference devoted to 100 Anniversary of R.N. Schljakov (Apatity, Murmansk Region, 2426 June 2012, Apatity) and field school "Bryophytes of Subarctic" for beginners in bryology (Apatity, Murmansk Region, 27-30 June 2012, Apatity). - Бот. журн. [Bot. Zhurn.] 98(3): 398-404.

AFONINA, O.M., I.V. CZERNYADJEVA, V.R. FILIN, M.S. IGNATOV, E.A. IGNATOVA \& Yu.S. MAMONTOV. 2013. New moss records from Zabaikal'sky Territory. 5. - Arctoa 22: 255-256.

[AFONINA, O.M., Ts. TSEGMED \& E. ENKHJARGAL] АФОНИНА О.М., Ц. ЦЭГМЭД, Э. ЭНХЖЖАРГАЛ. 2013. Новые находки мхов в Монголии. - [New moss record from Mongolia] Arctoa 22: 258.

AFONINA, O.M., E.A. IGNATOVA, V.E. FEDOSOV \& O.I. KUZNETSOVA. 2014. Toward a new understanding of Syntricia submontana (Pottiaceae, Bryophyta). - Arctoa 23: 11-24.

AFONINA, O.M., I.V.CZERNYDJEVA \& V.R. FILIN. 2014. New moss records from Zabaikal'sky Territory. 6. - Arctoa 23: 233-234.

[AFONINA, O.M., E.I IVANOVA \& K.K. KRIVOSHAPKIN] АФОНИНА О.М., Е.И. ИВАНОВА, К.К. КРИВОШАПКИН. 2014. Новые находки мхов в Республике Саха (Якутия). 5. [New moss records from Republic of Sakha (Yakutia). 5.] Arctoa 23: 234.

AFONINA, O.M. \& H. KÖCKINGER. 2014. Anomobryum bavaricum (Warnst. in Hamm.) Holyoak et Köckinger. - In: Ellis L.T. (ed.) New national and regional bryophyte records. J. Bryol. 32(2): 134-151.

[AFONINA, O.M. \& Yu.S. MAMONTOV] АФОНИНА O.M., Ю.С. МАМОНТОВ. 2014. Бриофлористические находки в верховьях р. Койра (Забайкальский край, Становое нагорье). - [New records of mosses and liverworts from the Upper Kojra River (Zabaikal'sky Territory, Stanovoe Plateau)] Проблемы ботаники Южной Сибири и Монголии: сборник научных статей по материалам ХІІІ международной научно-практической конференщии, г. Барнаул, 20-23 октября 2014 г. [Problemy botaniki Yuzhnoj Sibiri i Mongolii: sbornik nauchnyh statej po materialam XIII mezhdunarodnoj hauchno-prakticheckoj konferencii, Barnaul, 20-23 October 2014)] Барнаул [Barnaul]: 30-32. 